
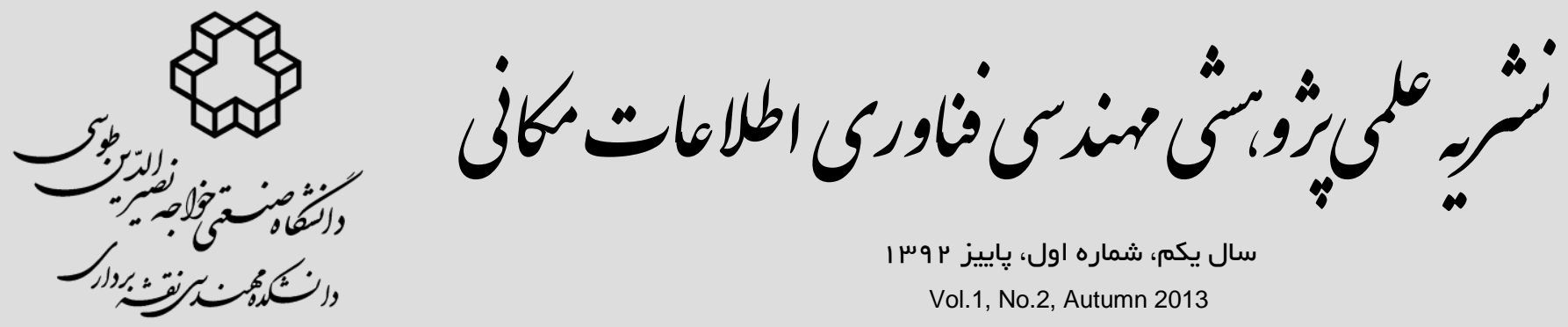

سال يكم، شماره اول، ياييز ب وسر

Vol.1, No.2, Autumn 2013

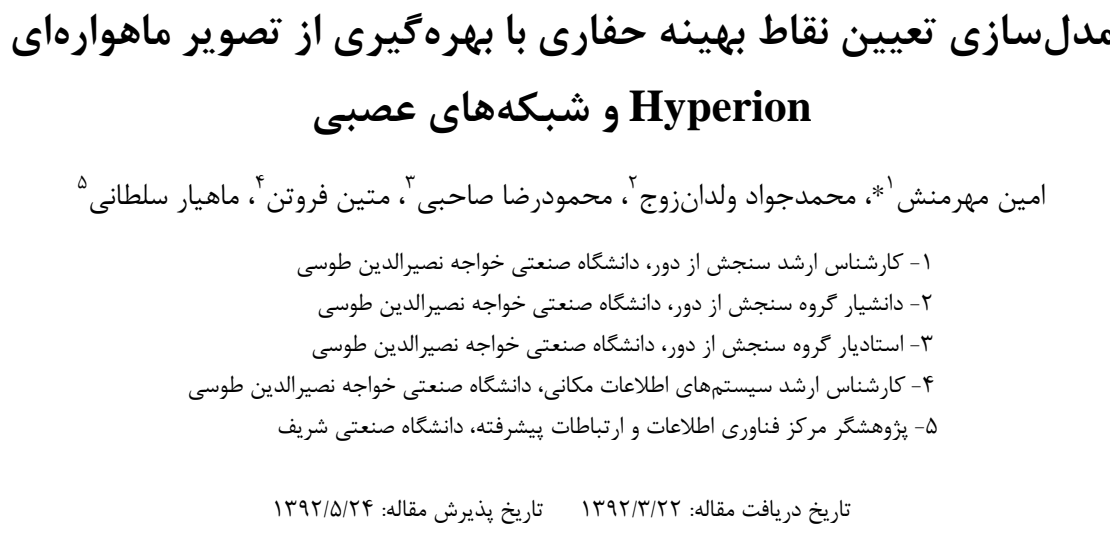

جـكيده

از اهداف اساسى و اوليه در مطالعات تفصيلى اكتشاف منابع معدنى، تفكيك آلتراسيونهاى معدنى بهمنظور مدلسـازى شـكل و موقعيـت تودههاى معدنى و تهيه نقشه نقاط بهينه حفارى است. نخستين هدف اين مقالـه تفكيـى آلتراسـيونهـاى معـدنى در تصـوير مـاهوارهاى فراطيفى Hyperion با استفاده از دو روش SAM و نسبت باندى است. در ادامه با استفاده از شبكههاى عصبى يرسـيترون خندلايـه و تـابع شعاعمبنا، به منظور تلفيق لايههاى مؤثر بر كانىسازى مس يورفيرى و لايه آتراسيون حاصل از طبقهبندى تصـوير، هــف دوم كـه همـان

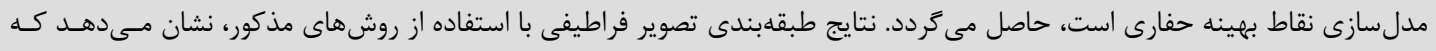

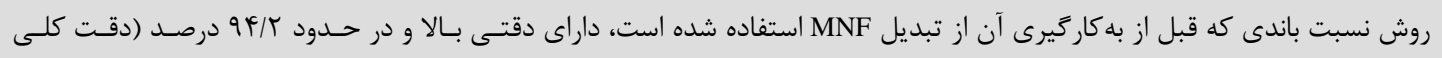
بهدست آمده از ماتريس خطا) است. نتايج بهرهگيرى از شبكه هاى عصبى در مدلسازى تعيين نقاط بهينه حفارى نيز نشان مسىدهـد كـهـ

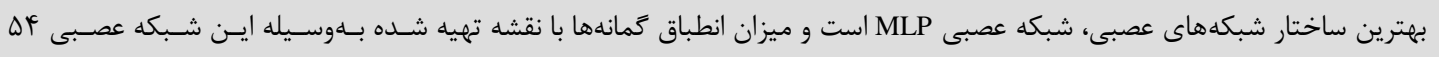
درصد است.

كليدوازهها: تصوير فراطيفى، آلتراسيون، مس يورفيرى، شبكه عصبى، سنجنده Hyperion.

* نويسنده مكاتبه كننده: تهران، خيابان وليعصر (عج)، بالاتر از تقاطع ميرداماد، يلادى وعبا ا، دانشكاه صنعتى خواجه نصيرالدين طوسى، دانشكده مهندسى نقشهبردارى. Email: amin1174@gmail.com

تلفن: ANVAGTIT 


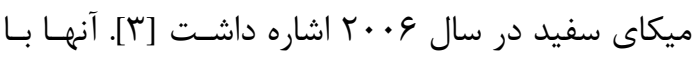

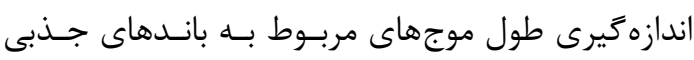

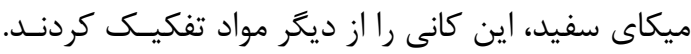

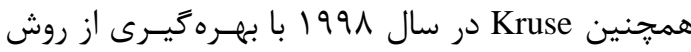

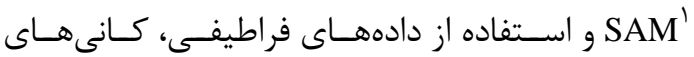

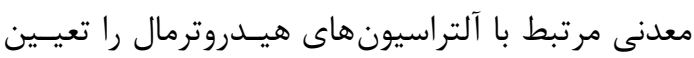

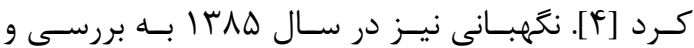

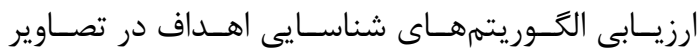

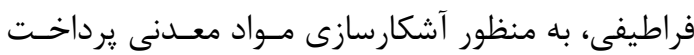

در زمينه بهره

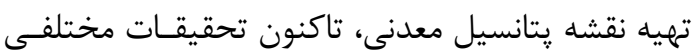

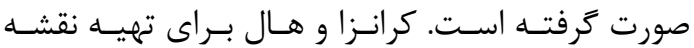

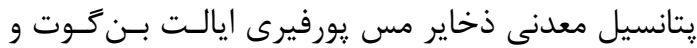

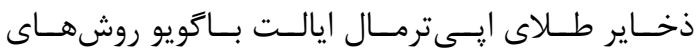

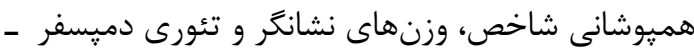

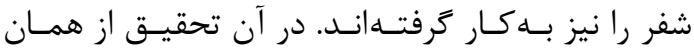

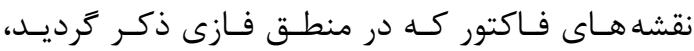

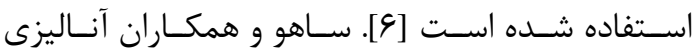
جندضـابطهاي در محسيط GIS را بـهمنظــور تشـخيص نواحى يتانسيلدار ذخاير طلا در منطقه هـاتى ماسكى دئى

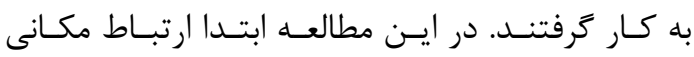
فاكتورهاى تشخيص كانىسازى با توجه به ذخيـرهــاى معدنى شناخته شده، به صورت تجربى تجزيه و تحليـل

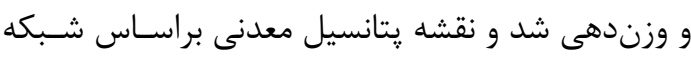
استنتاجى ارائه شده، تهيه كرديد [V]

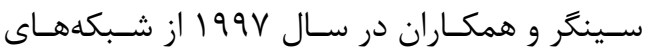
عصبى براى تخمين فاصله از ركههاى معـدنى اسـتفاده

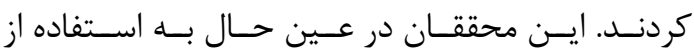

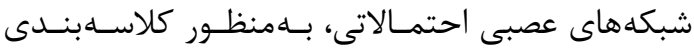
ركهذهاى معدنى اقدام كردند [^]. آنهـا در سـال 1999 نيز دست به مقايسه نقشه پِتانسيل معسدنى تهيـهـ شــده بلهوسيله شبكه هـاى عصـبى و وزنهـاى نشـانكر زدنــد.

1. Spectral Angle Mapper
| - 1- (- مقدمه

مدلسـازى تعيـين منــاطق حفـارى، از يــيشنيازهـاى

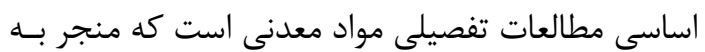
كاهش هزينه هاى فرايند حفارى و تسهيل مـدل سـازى شكل و موقعيـت تـودههـاى معسدنى مسىشـود. تعيـين مناطق بهينه حفارى مستلزم تلفيق فاكتورهاى مؤثر بـر

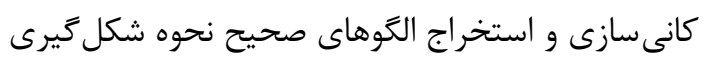
ذخاير معدنى از ميان اطلاعات زمينشناسى، زئوفيزيك

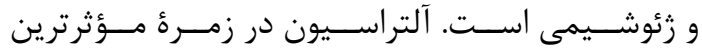

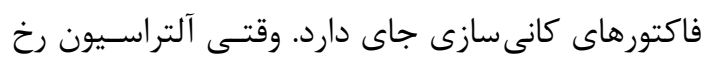

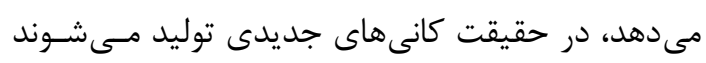

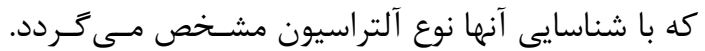

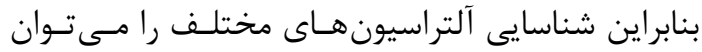
كامى اساسى در مدل سازى شكل و موقعيت تـودههـاى مختى

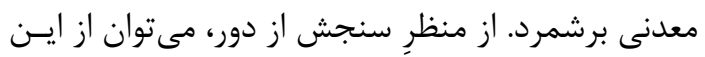

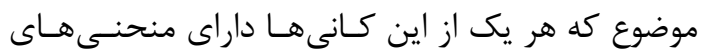
طيفى مخصوص به خود هستند، به عنوان وجه تمايزى

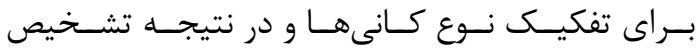

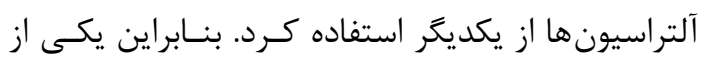
روشهاى متداول در تفكيك آلتراسيونهـا، اسـتفاده از تصاوير ماهوارهاى است.

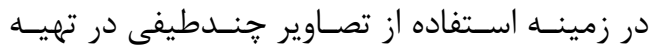

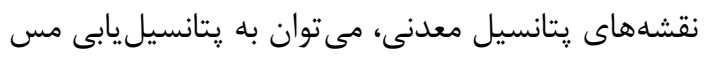

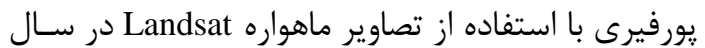
هیr| بهوسيله خودرس اشاره كـرد [1]. او در تحقيـق خود با بهره خيرى از روشهاى مؤلفههـاى اصلى و نيـز

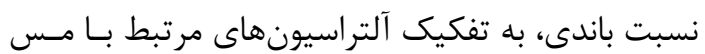
يـورفيرى يرداخـت. رنجبــر و همكـارانش نيـز در سـال

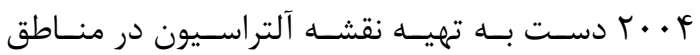

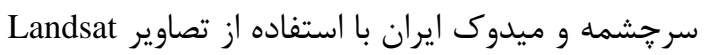
, رند در زمينه استفاده از تصاوير ابرطيفى در تهيه نقشـهـ يتانسيل معدنى نيز مى توان به تحقيـق صـورت گرفتــهـ

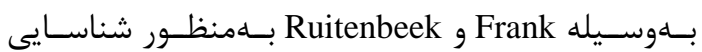


r- روش هاى طبقهبندى SAM

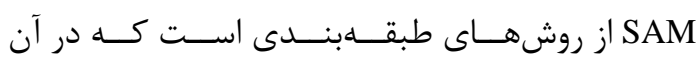

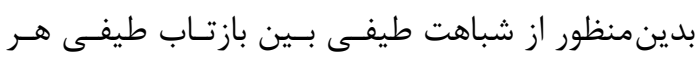

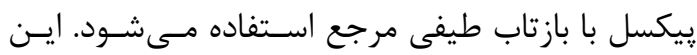

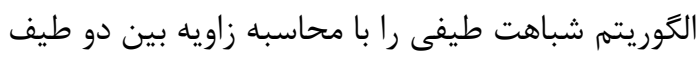

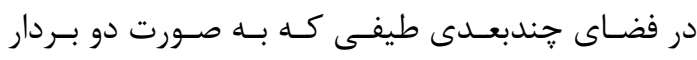
مشخص مىشوند تعيين مى كند (شكل هاى ا و r). اين الكوريتم را مى توان به فضاى nبعدى تعمـيم داد. زاويسه

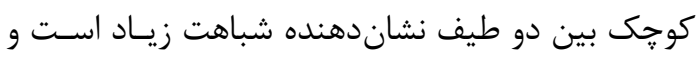

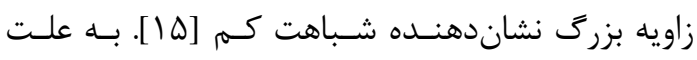

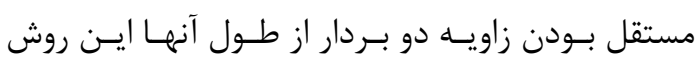

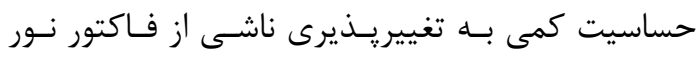

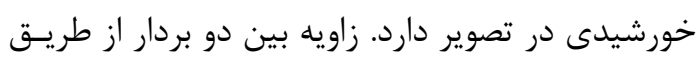
رابطه (1) محاسبه مىشود [ه و ه هائ.

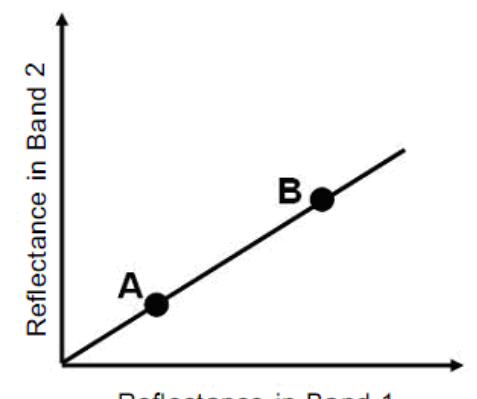

Reflectance in Band 1

شكل 1. دو طيف مشابه [19]

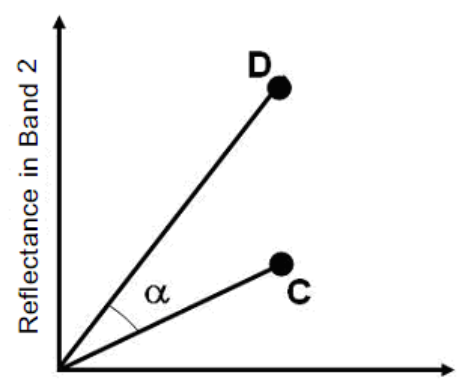

Reflectance in Band 1

شكل r. دو طيف غيرمشابه [19]
نتايج اين تحقيق نشان مى داد كه ميزان خطا (با مقـدار

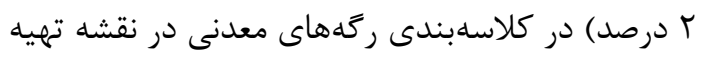

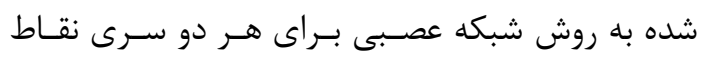
تست و آموزش، به مراتب كمتر از ميزان خطا (با مقـدار

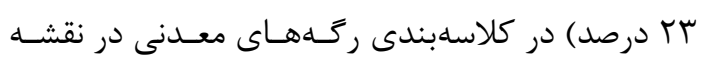

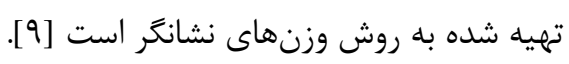

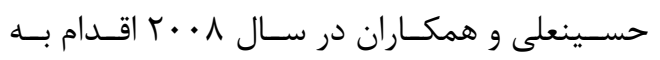
وزندهى لايههاى اطلاعاتى در كانسـار مسس على آبـاد

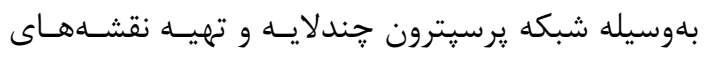

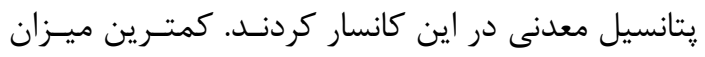

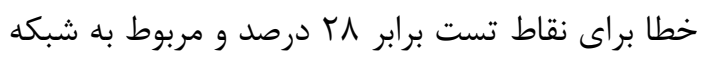

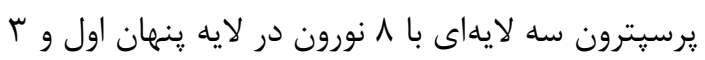
نورون در لايه ينهان دوم ارزيابى شد [ـ •1].

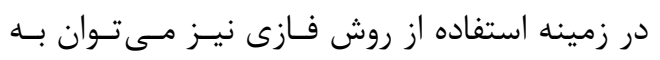

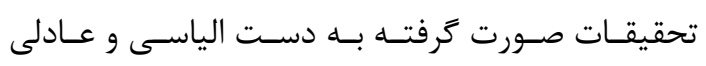
بهمنظور استفاده از روش فازى در تعيين مناطق بهينـه حفارى در دو منطقه نوزهـون و جــاهفيـروز اشـاره كـرد. بيشترين ميزان دقت نقشههاى تهيه شده به روش فازى دون

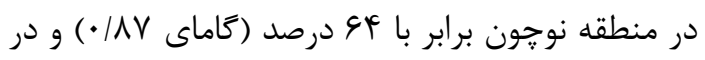

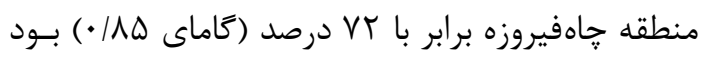

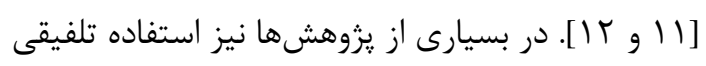

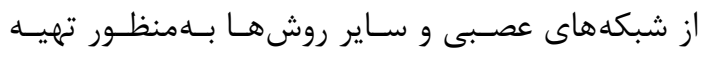
نقشههاى يتانسيل معدنى انجام شده است. از جمله اين موارد مى توان به تلفيق شبكههــاى عصـبى و اطلاعـات

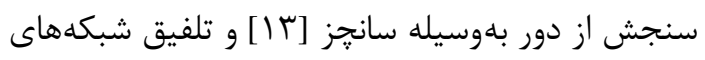
عصبى به همراه مجموعه هاى فـازى بـهـوسـيله يـوروال

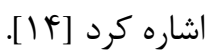
هـدف اصـلى ايـن تحقيـق بهــرهيــرى از تصـوير Hyperion كانى سازى مس يورفيرى، با اسـتفاده از دو روش SAM

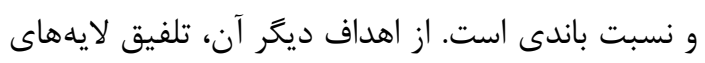

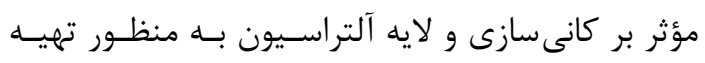

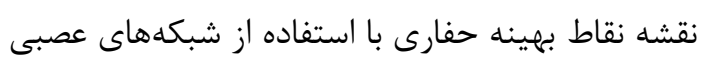

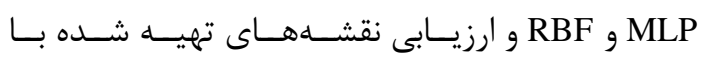
كمانههاى موجود است. 
روش، ابتدا طيف تصوير به فضاى MNF برده مىشـود

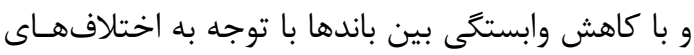
طيفى كانى ها در اين فضا، تعدادى از نسبتهاى بانسدى بdمنظور طبقهبندى مورد استفاده قرار مى گيرند.

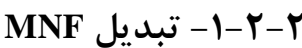
در استفاده از داده ابرطيفى، بهتر است كـهـ نـويز و نيـز ابعاد داده كاهش يابند. تبديل MNF بــه عنــوان تبـديل

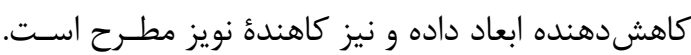
اولين مرحله تبديل MNF را مىتوان در ه بخش تعيين نويز تصوير، محاسبه ماتريس كوواريانس نـويز تصـوير و

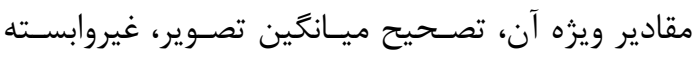
كردن نويز در تصوير و نرمـال سـاختن نـويز خطـى در مريك داده توصيف كرد. حاصل اين ه مرحله، داده نويز سفيد شده و با تصحيح ميانگين شده است كه در مرحلـه دوم

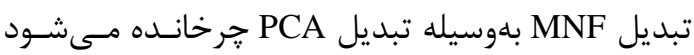

[IV]

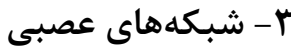

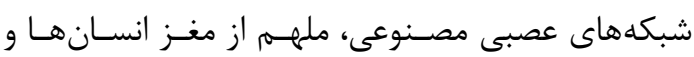

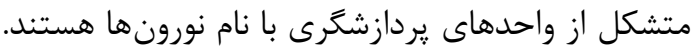

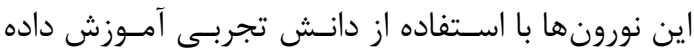

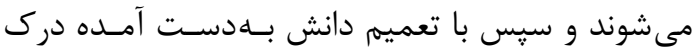

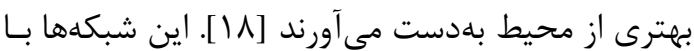

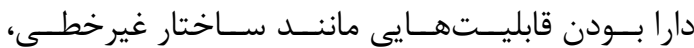

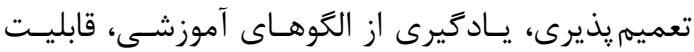

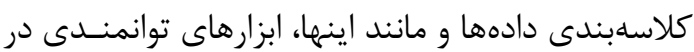
علوم اكتشاف معدنى بهشـمار مسىرونسـد. در ادامـهـ ايـن بخش به بررسى ساختار دو نوع شبكه عصبى كه از آنها

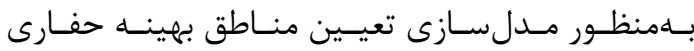
استفاده شده است، يرداخته مىشود.

1. Band Ratio

2. Minimum Noise Fraction Transformation
در رابطه (1)، بردار t طيف مورد آزمـايش و بـردار طيف مرجع است. مهممترين مزيت اين الخوريتم سادگى درى ساختار آن و استفاده سريع براى نمايش شباهت طيفى بين طيف تصوير و طيـف مرجـع اسـت. البتـهـ مشـكل

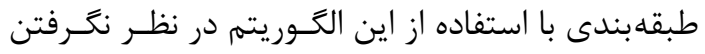

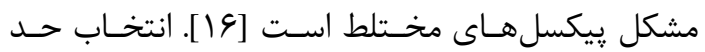

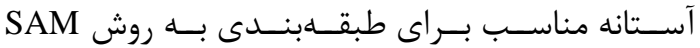

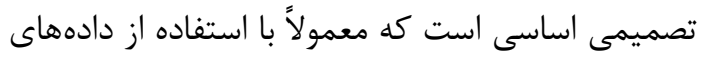
معلوم از منطقه مورد استفاده تعيين مى گرددد. $\alpha=\cos ^{-1}\left[\frac{\overrightarrow{\mathrm{t}}[\overrightarrow{\mathrm{r}}}{\|\overrightarrow{\mathrm{t}}\| \cdot\|\overrightarrow{\mathrm{r}}\|}\right]$ رابطه (1) لازم به ذكر است كه دادههاى آموزشى براى تعيـين بردار مرجع در اين روش از شركت ملى مسس برگرفتـه

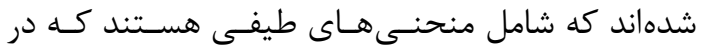

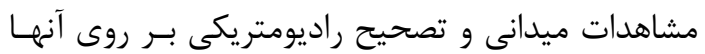
بلهوسيله همين شركت صورت يذيرفته است.

\section{r-r - روش نسبت باندى'}

در روش نسبت باندى به جاى اسـتفاده از كـل منحنـى طيفى از تعدادى طول موج و نسبت مقادير آنها استفاده مىشود. از آنجا كه طيفهاى مرجع اغلب فقط در گند طول موج اختلاف هايى با يكديخر دارند و در ديخر طول

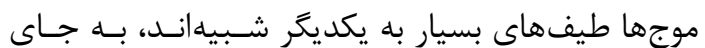
استفاده از كل طـول مـوجهـا (كـل منحنـى طيفـى) از نسبت دو يا جند باند نيز مـى تـوان بـراى طبقــــــــى

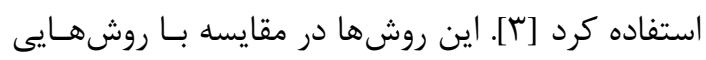
كه مبناى آنها مقايسه دو منحنى طيفى است، به ميزان اندكى از خطاهاى مربوط به فرايند تصـحيح اتمسـفرى تأثير مى يذيرند [r].

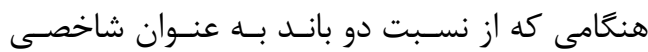
براى جداسازى دو ماده استفاده مىشود، هر قدر اين دو باند وابستتى كمترى به يكـديخر داشـته باشــد نتـايج

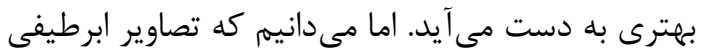

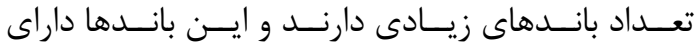
وابستخى هاى طيفىاند [V]. بنابر اين در استفاده از ايسن 


\section{مدلسازى تعيين نقاط بهينه حفارى با ...}

امين مهرمنش و همكاران

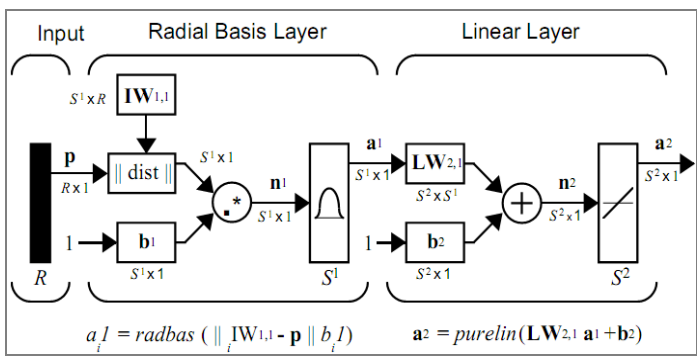

شكل r. شبكه عصبى شعاعمبنا [1ه]

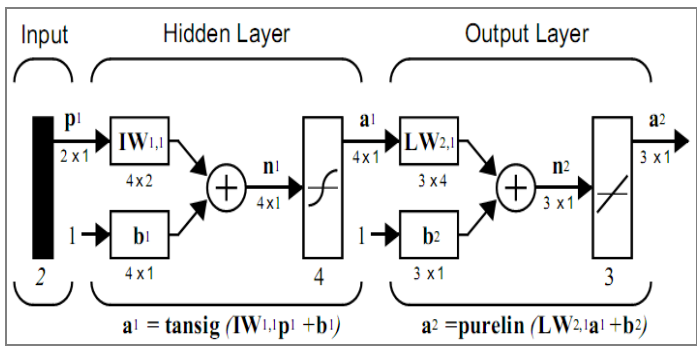

شكل f. شبكه يرسيترون קندلايه [1ه]

F

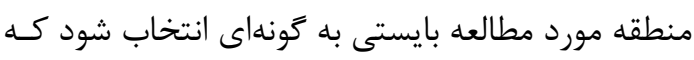

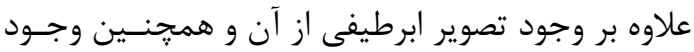

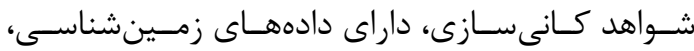

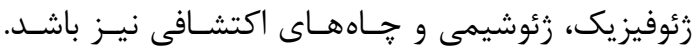

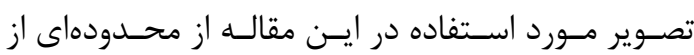

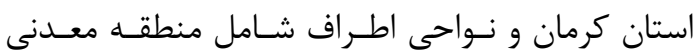
نوجون بركرفته شده است. اين تصوير كه از سنجنده Hyperion بهدست آمـده

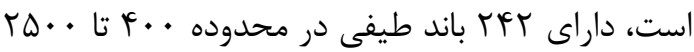

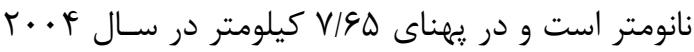

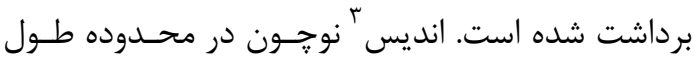

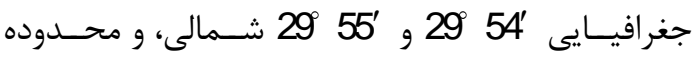
عرض جغرافيـايى 50 و و $55^{\circ} 51$ شـرقى، در جههار كيلومترى جنوب غربى معدن سرجشمه، واقع در استان

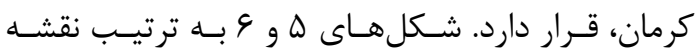

1. Radial Basis Function

2. Multi Layer Perceptrons

r. هر نوع اثر و نشانهاى را از هر كانى معدنى، انديس مىنامند. r-1- تابع شعاعمبنا ' (RBF)

شبكههاى عصبى شعاعمبنا علاوه بر لايه ورودى، از يك

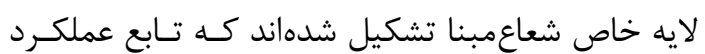
اين لايه برمبناى توزيع گوسين است. اين تـابع، فاصـله

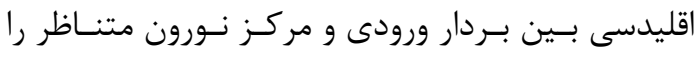

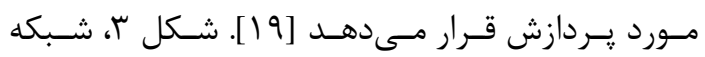
شعاعمبنا را نشان مى دهد. در اين شكل، بردار ورودى با لـا نماد p، لايه شعاعمبنــا بـا نمــاد dist، بـردار وزن ميـان

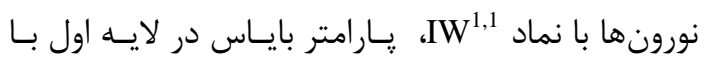

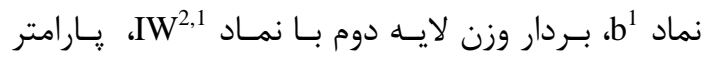

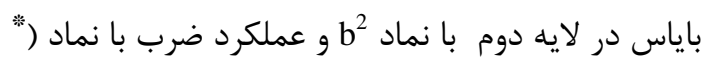

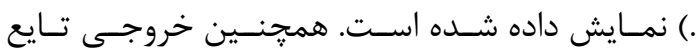

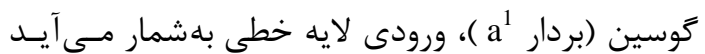

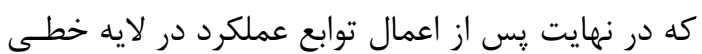

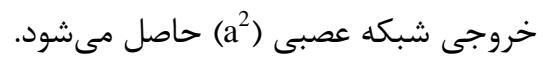

\section{r-r-r- شبكه يرسيترون جندلايه} شبكه هاى يرسيترون جندلايه در زمـره يركـاربردتـرين

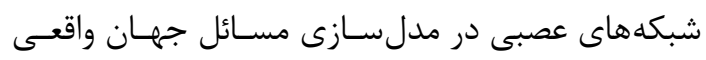

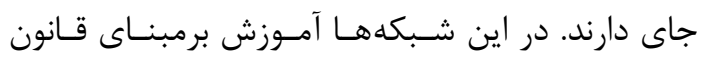
يسانتشار خطا صورت مى گيرد [19]؛ بدين ترتيب كـه

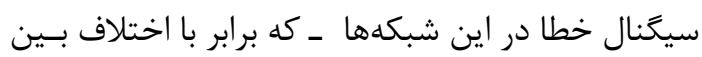

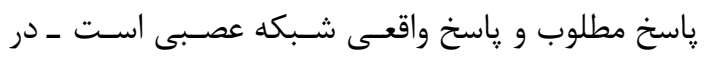
لايه خروجى تشـكيل مسىشـود و مقــدار خطـا يسس از

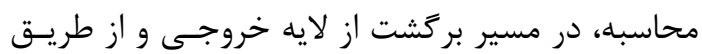

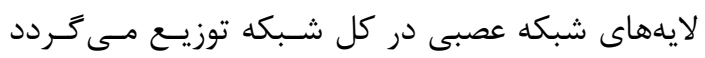

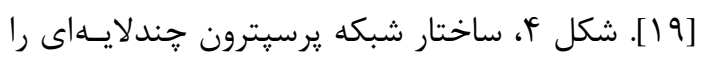

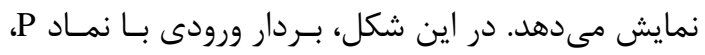

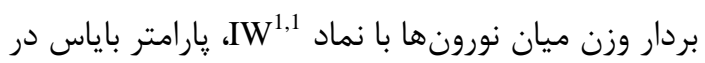
لايه اول با نماد

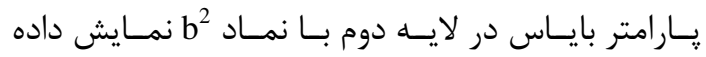

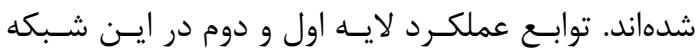
بلترتيب، توابع Tansig و Pureline هستند. 


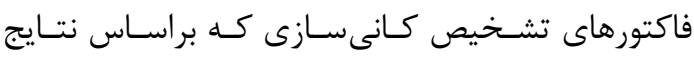

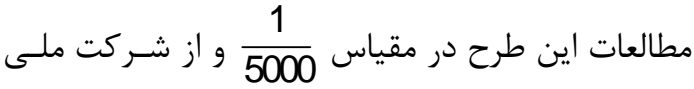

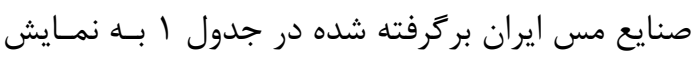

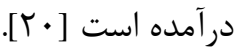

ه- - ج- جمع آورى و آمادهسازى لايه هاى اطلاعاتى

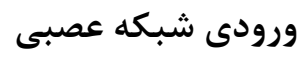

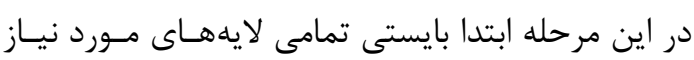

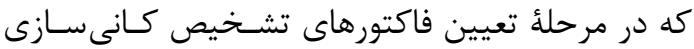

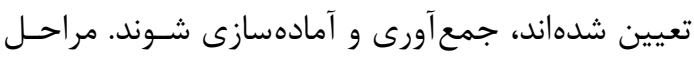

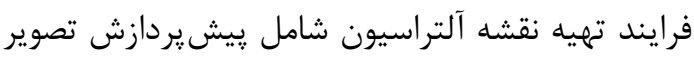

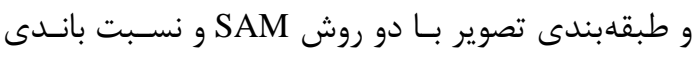
است. ساير نقشههاى لايههاى اطلاعاتى مورد نظر شامل

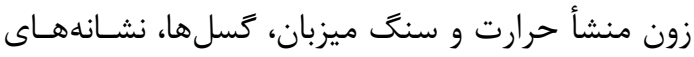

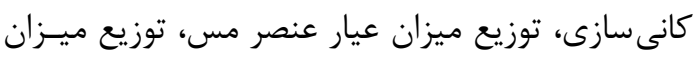
عيار عنصر موليبدن، توزيع ميزان اديتيو عناصر مسس و ونسي موليبــن، توزيــع ميـزان شـارزابيليتيه، توزيــع ميـزان

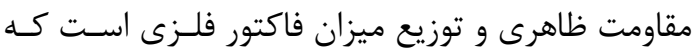

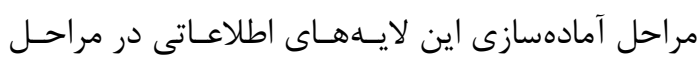
بعدى تشريح كرديده است.

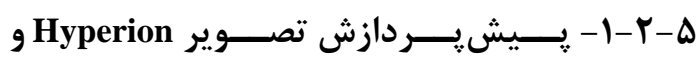
تفكيك آلتراسيونها

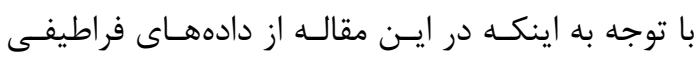

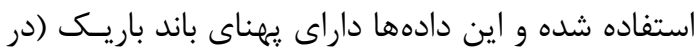

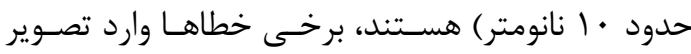

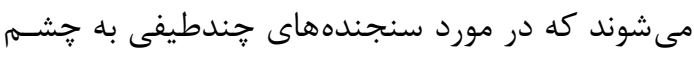

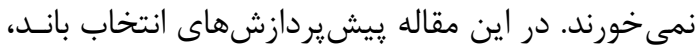

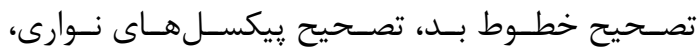

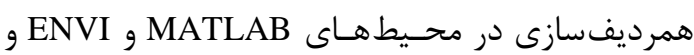
تصحيح اتمسفرى با استفاده از برنامه FLASH صـورت دمرت يذيرفت. اطلاعات بيشتر در زمينه مدل سازى خطاهـاى

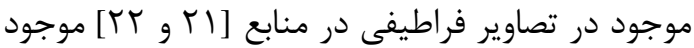

انديس نوجون و تصوير مورد استفاده را نشان مىدهنـد. در شكل צ، انديس نوجون با كادر مشخص شون شده است.

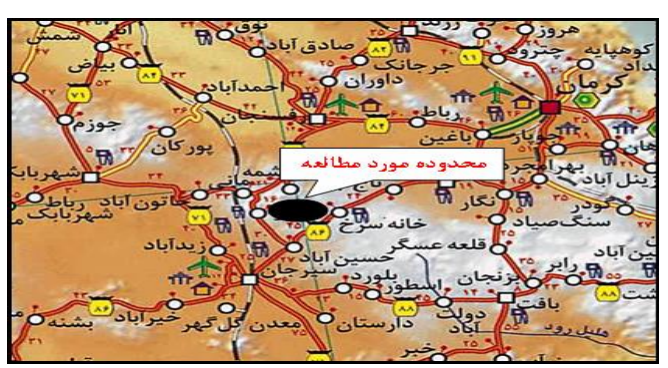

شكل ه. راههاى دسترسى انديس مس نوجون [•r]

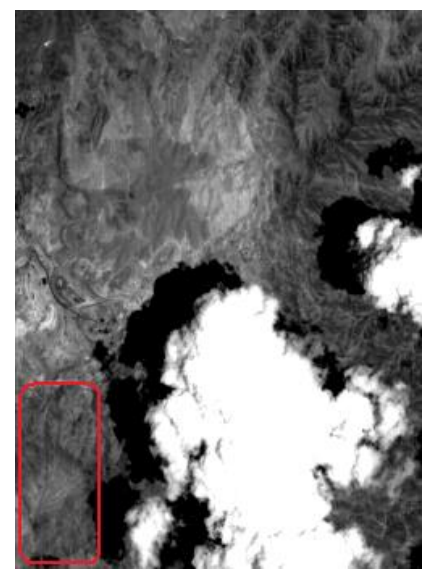

شكل 9. تصوير منطقه مورد مطالعه (باند 9.1)

$$
\text { ه- روش اجرا }
$$

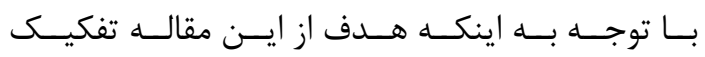
آلتراسيون هاى مربوط به مس يـورفيرى و تهيـهـ نقشـهـ

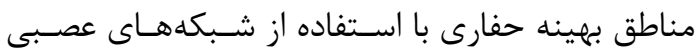

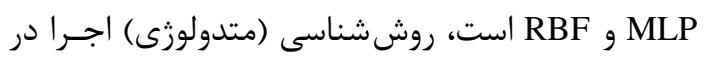
شكل V به نمايش در آمده است.

ه-1 - تعيين فاكتورهاى تشخيص كانىسازى

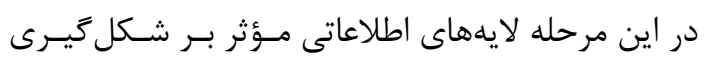

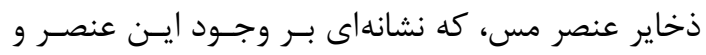

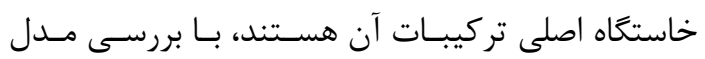

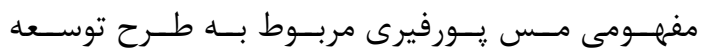
سيستمهاى اطلاعاتى مكانى شركت ملى صـنايع مس نس

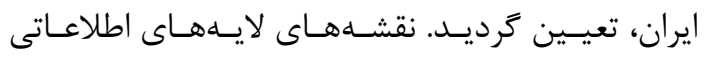


مدلسازى تعيين نقاط بهينه حفارى با ...

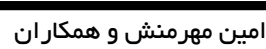

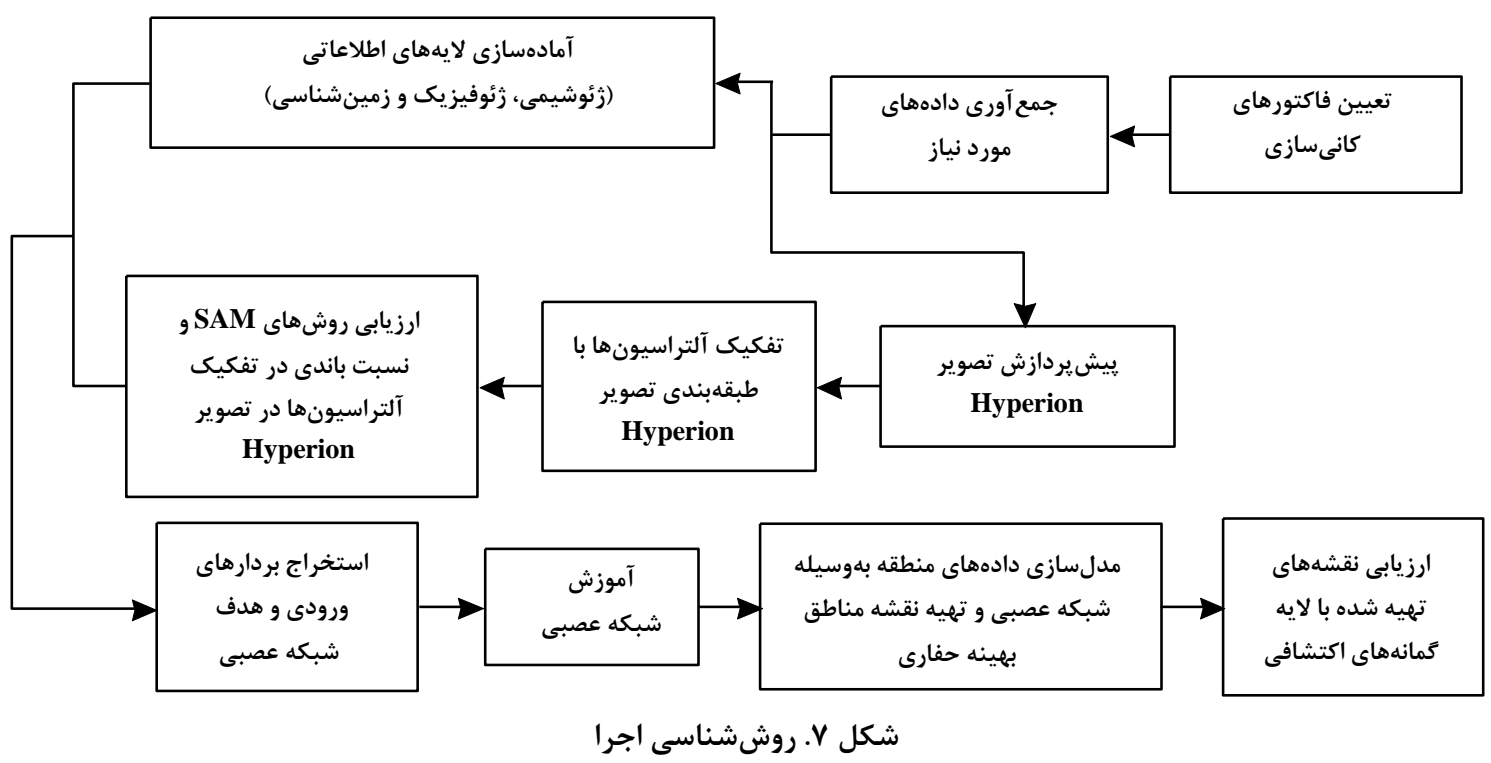

جدول ا. فاكتورهاى كنترل كننده كانىسازى [•r]

\begin{tabular}{|c|c|}
\hline نقشه هاى موجود & فاكتورهاى كانىسازى \\
\hline نقشه زون منشأ حرارت و سنگ ميزبان & \multirow{3}{*}{ 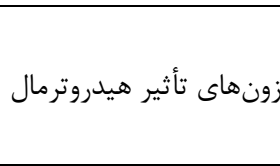 } \\
\hline نقشه آلتراسيون هيدروترمال & \\
\hline نقشه نشانههاى معدنى محلى & \\
\hline نقشه كَلهاى اصلى & كسلها \\
\hline نقشه عيار يكعنصرى (آنومالى مس_آنومالى موليبدن) & \multirow{2}{*}{ آنومالى رئوشيمى } \\
\hline نقشه عيار حُندعنصرى (انديسهاى اديتيو مس و موليبدن) & \\
\hline نقشه زون ناهنجارى مقاومت ظاهرى & \multirow{3}{*}{ آنومالى رئوفيزيك } \\
\hline نقشه زون ناهنجارى فاكتور فلزى & \\
\hline نقشه زون ناهنجارى شارزابيليته & \\
\hline
\end{tabular}

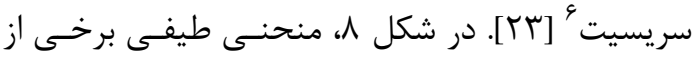
اين كانىها نشان داده شده است.

لازم به ذكر است كه به دليل ضعيف يا قـوى بـودن

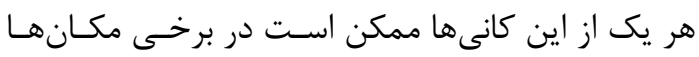

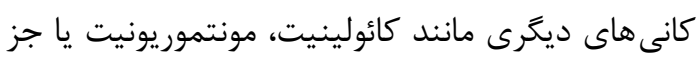

1. Propyllitic

2. Phyllic

3. Epidote

4. Chlorite

5. calcite

6. sericite

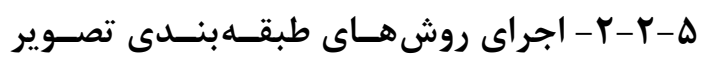

Hyperion

الف) اجراى الكوريتم SAM

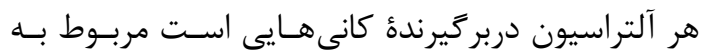

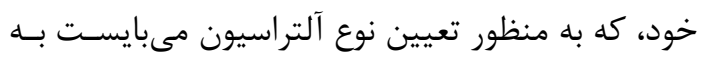

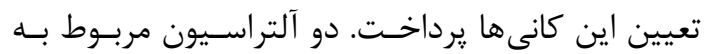

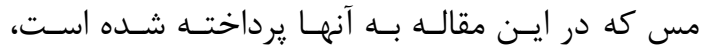

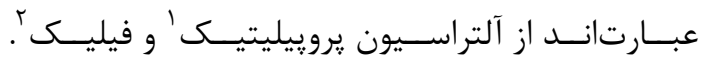
كانى هاى معروف تشكيل دهنده آلتراسيون يروييليتيـك

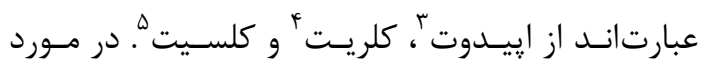

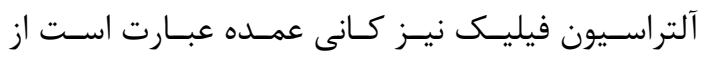


كانى وجود دارد. به عنوان مثال، يكى از ايـن حالـتهــا

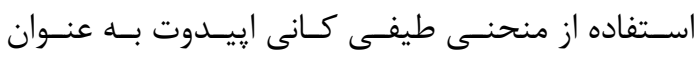
شاخصى براى آلتراسيون يروييليتيك و منحنسى طيفى إنى إنى كانى سريسيت براى آلتراسيون فيليك است. در اينجا از r حالتى كه در ادامه ذكر مى كردد استفاده شده است.

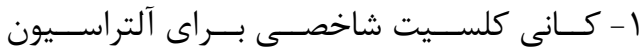
يروييليتيك و كانى كائولينيت شاخصى براى آلتراسيون

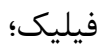

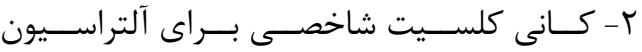
يروييليتيك و كانى سريسيت شاخصى براى آلتراسـيون إنسي

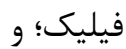

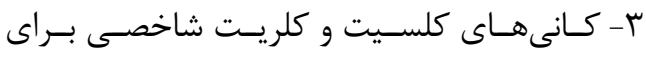

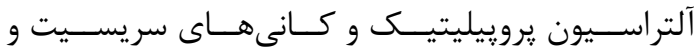
كائولينيت شاخصى براى آلتراسيون فيليك.

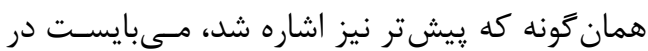

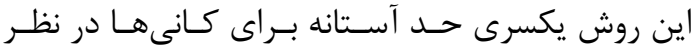

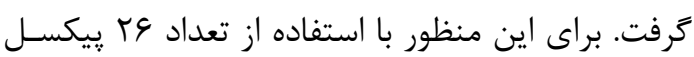

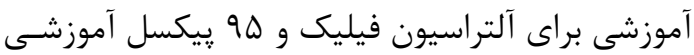

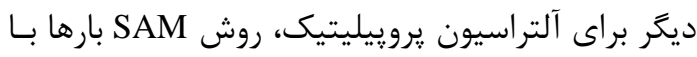

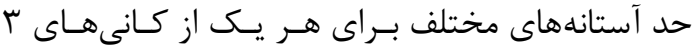

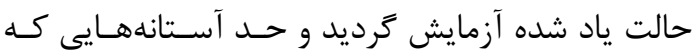

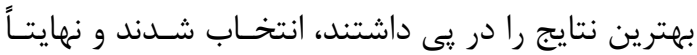

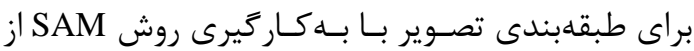

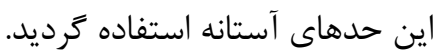

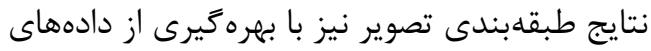

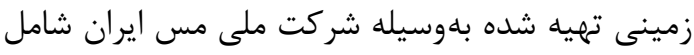

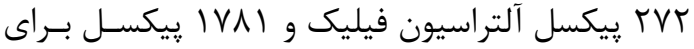

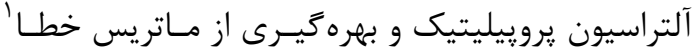

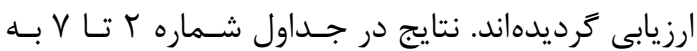

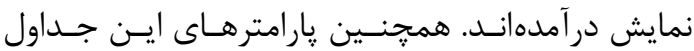

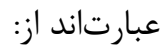

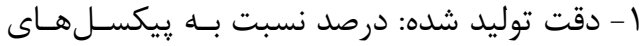

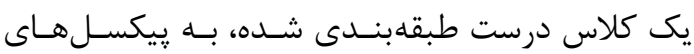

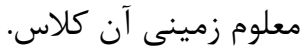

1. Confusion matrix
اينها نيز به جشم بخورد. از طرفى، فراوانى كانى هاى هر

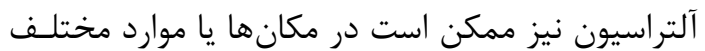

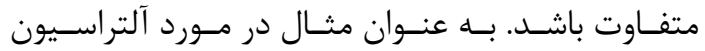

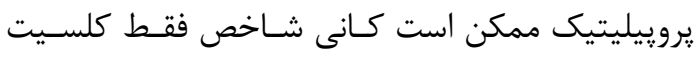

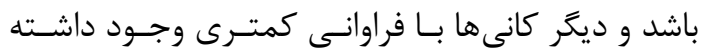
باشند. از اين رو براى تشـخيص ايسن دو آلتراسـيون بـا استفاده از روش SAM حالتهاى بسيار توناگونى بـراى

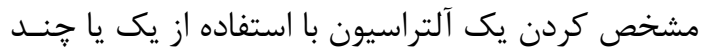

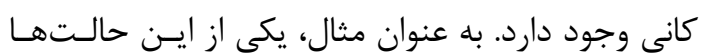

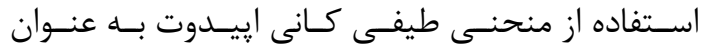

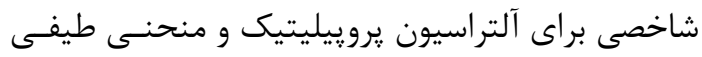

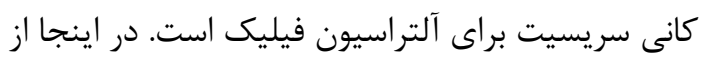
r حالتى كه در ادامه ذكر مى كردد استفاده شده است.

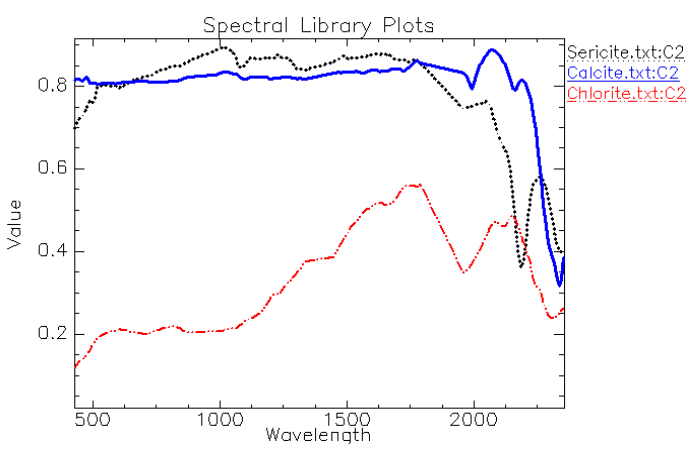

شكل ^. منحنى طيفى برخى از كانى هاى مرتبط با آلتراسيونهاى مس بوريفي برحى آزيرى

لازم به ذكر است كه به دليل ضعيف يا قـوى بـودن هر يكى از اين كانىها ممكن اسـت در برخسى مكـانهـا كانى هاى ديكرى مانند كائولينيت، مونتموريونيت يا جز اينها نيز به جشم بخورد. از طرفى، فراوانى كانى هاى هر

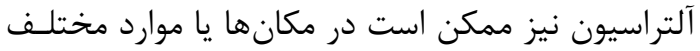

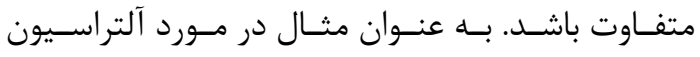

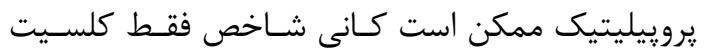

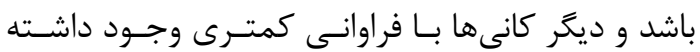
باشند. از اين رو براى تشـخيص ايسن دو آلتراسـيون بـا فـا

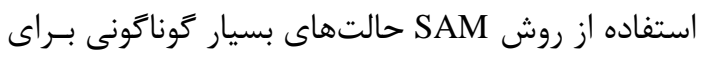

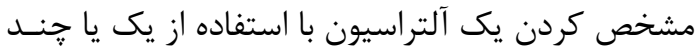


جدول F. نتايج طبقهبندى (برحسب درصد) براى حالت r

\begin{tabular}{|c|c|c|c|}
\hline كلاس & فيليك & يروييليتيك & جمع جم \\
\hline طبقهبندى نشده & $1 / F V$ & I/VF & $1 / V$ \\
\hline فيليك & $V \cdot 109$ & $N / I F$ & $19 / F T$ \\
\hline يروپييليتيك & $r V / q P^{r}$ & $9 \cdot 11 r$ & $\Lambda 1 / \Lambda \Lambda$ \\
\hline جمع جمع & $1 \cdots$ & $1 \cdots$ & $1 \cdots$ \\
\hline
\end{tabular}

جدول ه. دقتهاى توليدشده و كاربر براى حالت r

\begin{tabular}{|c|c|c|}
\hline كلاس & دقت توليدشده & دقت كاربر \\
\hline فيليك & $V \cdot 109$ & $\Delta \varepsilon / 9 \vee$ \\
\hline يروپييليتيك & 9.115 & $9 \Delta / 4 \wedge$ \\
\hline
\end{tabular}

ضريب كايا و دقت كلى به دسـت آمـده بـراى ايـن

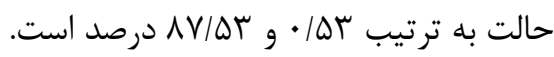

جدول \&. نتايج طبقهبندى (برحسب درصد) براى حالت ץ

\begin{tabular}{|c|c|c|c|}
\hline كلاس & فيليك & يرو بيليتيك & جمع \\
\hline طبقهبندى نشده & - & $\cdot \mid \Delta \varphi$ & $\cdot / 4 q$ \\
\hline فيليك & VA/TI & $11 / .9$ & $19 / 9 \mathrm{~V}$ \\
\hline ״روضييليتيك & $r 1 / 99$ & $\Lambda \Lambda / r \Lambda$ & $V q / \Delta F$ \\
\hline جمع & $1 \cdots$ & $1 \cdots$ & $1 \cdots$ \\
\hline
\end{tabular}

جدول V. دقتهاى توليد شده و كاربر براى حالت ץ

\begin{tabular}{|c|c|c|}
\hline كلاس - - & دقت توليدشده (درصد) & دقت كاربر (درصد) \\
\hline فيليك & VN/TI & $01 / 90$ \\
\hline يروييليتيك & $\Lambda \Lambda / K \Lambda$ & १९/४१ \\
\hline
\end{tabular}

ضريب كايا و دقت كلى به دسـت آمـده بـراى ايسن

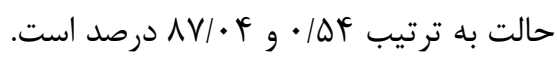

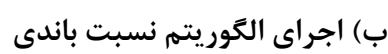

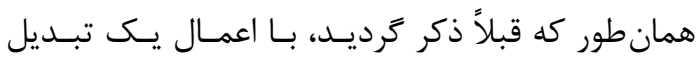

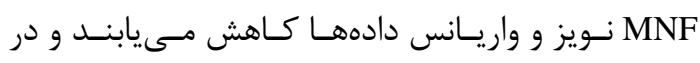

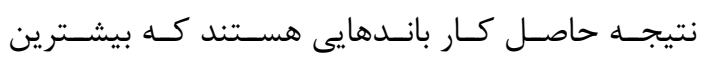

r- دقت كاربر: درصد نسـبت ييكسـلهــاى كـلاس درست طبقهبندى شده را به ييكسل هاى الكوريتم آنهـا در اين كلاس مشخص مىسازد.

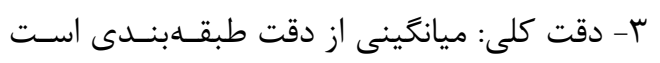

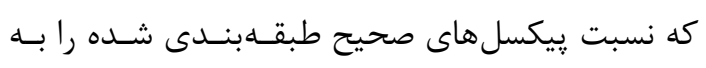
جمع ريكسل هاى معلوم زمينى نشان مي دهد.

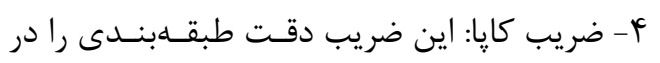
مقايسه با طبقهبندى كاملاً تصادفى نشان مى دهد و بـــ

$$
\text { اين صورت محاسبه مىشود: }
$$

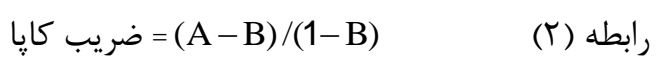

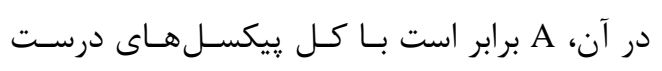

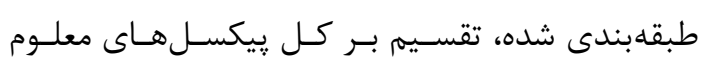

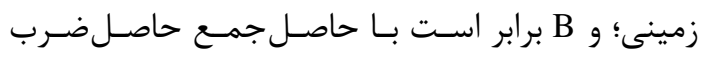
ييكسل هاى معلوم زمينى هـر كـلاس در ييكسـل هــاى طبقهبندى شده براى آن كلاس، تقسيم بر مجذور كـل معل

$$
\text { ييكسل هاى معلوم زمينى. }
$$

\begin{tabular}{|c|c|c|c|}
\hline كلاس & فيليك & يروييليتيك & جمع \\
\hline طبقهبندى نشده & • & $r / \Delta F$ & $\mu / \cdot V$ \\
\hline فيليك & $V \Delta / T V$ & $\Delta / 9)$ & $\mid f / \wedge \varphi$ \\
\hline يروِييليتيك & TY/gT & $q \cdot 1 \wedge \Delta$ & $\Lambda T / \cdot \Lambda$ \\
\hline جمع & $1 \cdots$ & $1 \cdots$ & $1 \cdots$ \\
\hline
\end{tabular}

جدول r. نتايج طبقدبندى (برحسب درصد) براى حالت

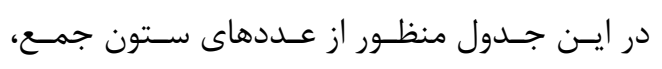

درصد نسبت ييكسل هاى هر كلاس به كل ييكسل هـاى r كلاس است.

\begin{tabular}{|c|c|c|}
\hline كلاس & دقت & دقت كاربر \\
\hline فيليك & $V \Delta / \mu V$ & $G V / T I$ \\
\hline يروييليتيك & $9 \cdot 110$ & $q 9 / \cdot r$ \\
\hline
\end{tabular}

جدول r. دقتهاى توليدشده و كاربر براى حالت ا

ضريب كايا و دقت كلى به دسـت آمـده بـراى ايـن

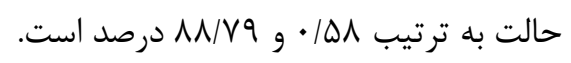




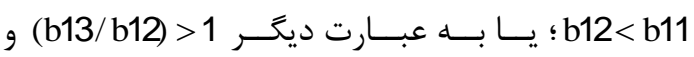

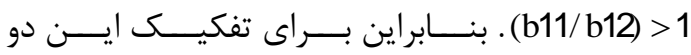

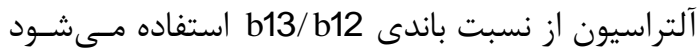

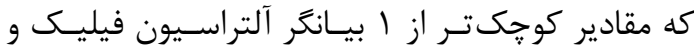

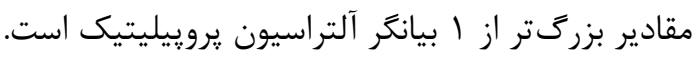

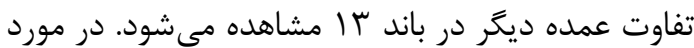

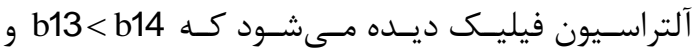

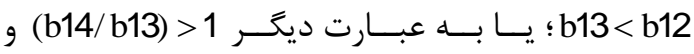

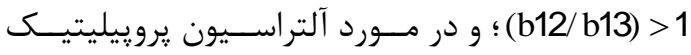

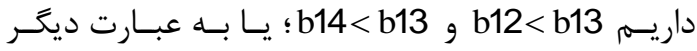

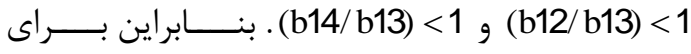
تفكيك اين دو آلتراسيون همزمان از نسبتهاي بانـاندى

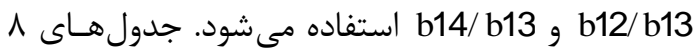

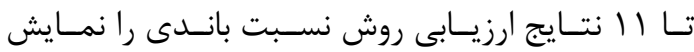
مى دهد.

جدول ^. نتايج طبقدبندى (برحسب درصد) براى حالت ا

\begin{tabular}{|c|c|c|c|}
\hline كلاس & فيليك & يروييليتيك & جمع \\
\hline طبقهبندى نشده & $r \cdot 199$ & $\cdot$ & r/VA \\
\hline فيليك & $\vee q / \cdot q$ & $r / \mathcal{F} \Lambda$ & $1 r / 4 q$ \\
\hline يروِيليتيك & - & $9 \& / \Delta T$ & NT/VR \\
\hline جمع & $1 \cdots$ & $1 \cdots$ & $1 \cdots$ \\
\hline
\end{tabular}

استقلال را از يكديكر دارند. در اينجا با توجه به مقـادير

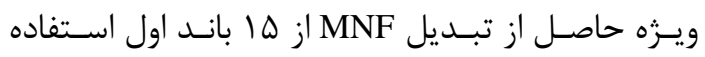

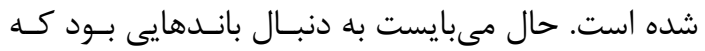

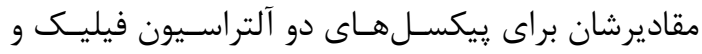

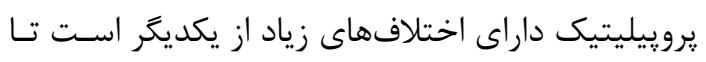

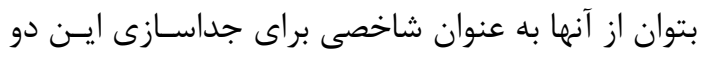

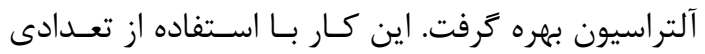

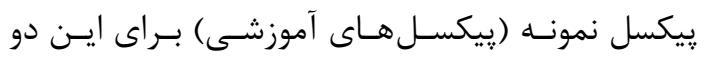
آلتراسيون و بررسى مقادير حداقل و متوسط و حـداكثر

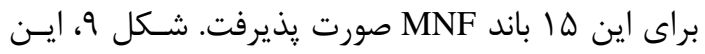

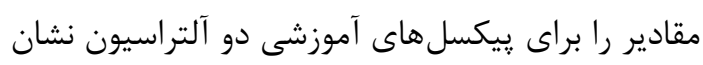
مى دهد.

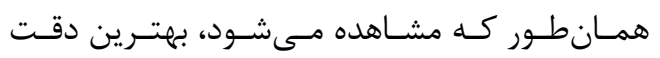
بهدست آمده در روش SAM، N1V9 درصد (حالـت () تفاوتهاى بسيارى را مى توان در اين منحنى ها ديد

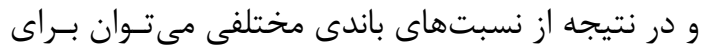

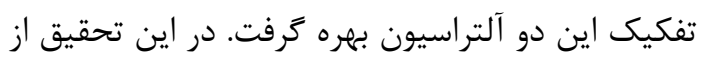

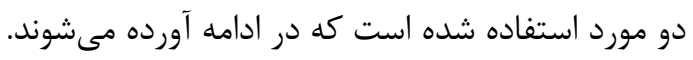

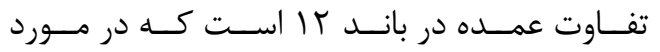

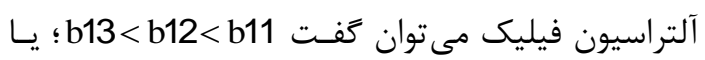

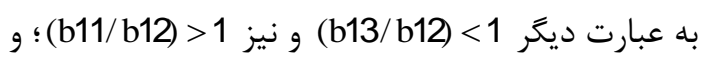

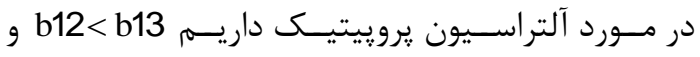
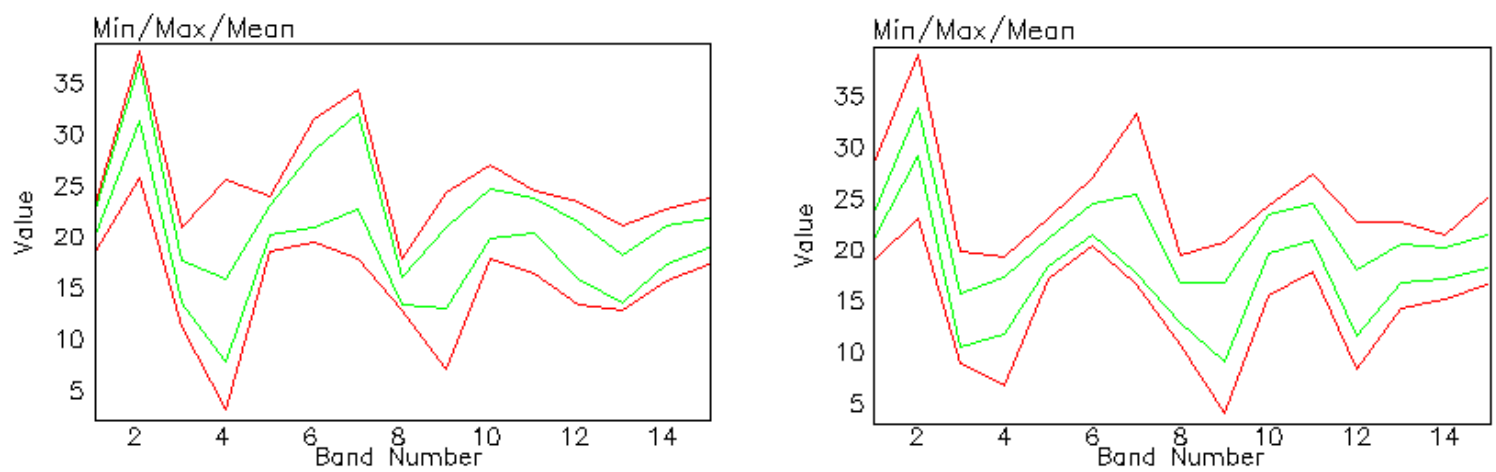

شكل 9. مقادير حداقل، متوسط و حداكثر براى ها باند MNF يِيكسل هاى نمونه آلتراسيون فيليك (سمت جٍٍ) و مقادير حداقل،

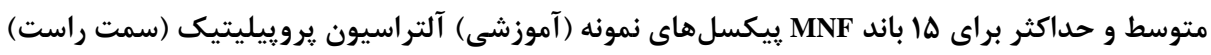




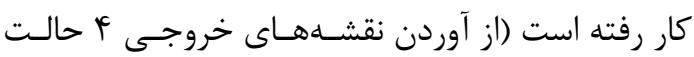

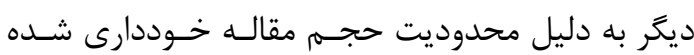

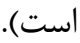

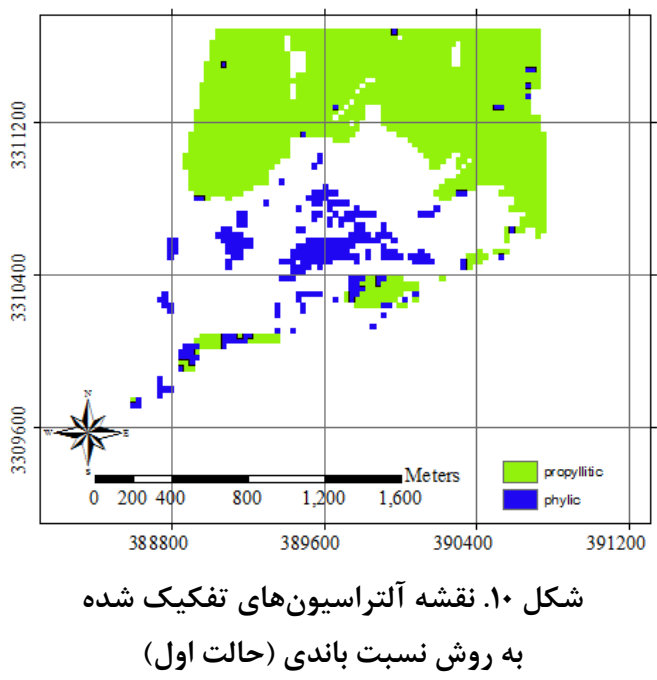

ه-r-r- - آمادهسازى دادههاى آموزشى ورودى

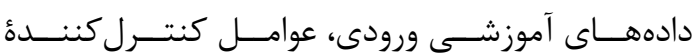
شكل گيرى ذخيره معدنى اند كه لازم اسـت ابتـدا بـراى

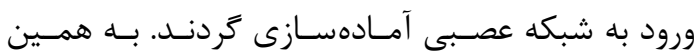

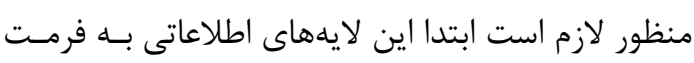
رسترى با سايز ريكسل يكسـان تبـــيل شـوند. لازم بــهـ

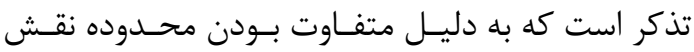

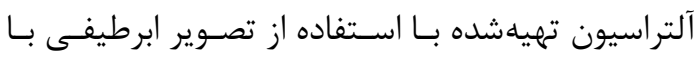

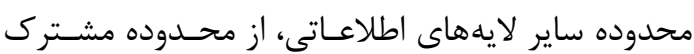

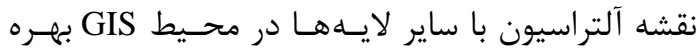

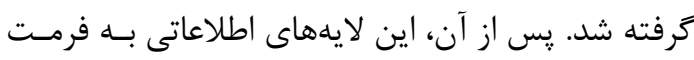

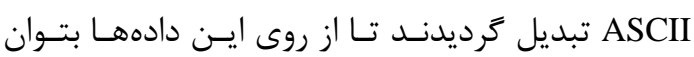
بردارهاى آموزشـى ورودى شـبكه عصـبى را اسـتخراج

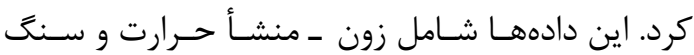
ميزبان، كسل ها، نشانههاى كـانى سـازى، توزيــع ميـزان

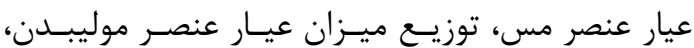
توزيع ميزان شارزابيليتيه، توزيع ميزان مقاومت ظاهرى

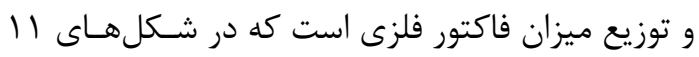
تا 11 ا نمايش داده شدهاند.
جدول 9. دقتهاى توليد شده و كاربر براى حالت

\begin{tabular}{|c|c|c|}
\hline كلاس & دقت توليدشده & دقت كاربر \\
\hline فيليك & $\vee q / \cdot p$ & VV/GT \\
\hline يروِيليتيك & $q \& / \Delta T$ & $1 \cdots$ \\
\hline
\end{tabular}

ضريب كايا و دقت كلى به دسـت آمـده بـراى ايـن حالت به ترتيب VV/ • و / / 9 درصد است.

جدول •1. نتايج طبقهبندى (برحسب درصد) براى حالت r

\begin{tabular}{|c|c|c|c|}
\hline كلاس & فيليك & يروييليتيك & جمع \\
\hline طبقهبندى نشده & TI/Ta & $1 / 9 \mathrm{~V}$ & $\Delta / \wedge \Delta$ \\
\hline فيليك & GN/VD & - & $9 / 11$ \\
\hline يروضييليتيك & - & $9 \Lambda / \cdot r$ & $\Lambda \Delta / \cdot \Delta$ \\
\hline جمع & $1 \cdots$ & $1 \cdots$ & $1 \cdots$ \\
\hline
\end{tabular}

جدول Iا. دقتهاى توليدشده و كاربر براى حالت r

\begin{tabular}{|c|c|c|}
\hline كلاس & دقت توليد شده & دقت كاربر \\
\hline فيليك & GN/VD & $1 \cdots$ \\
\hline يرووييليتيك & $q \Lambda / \cdot r$ & $1 \ldots$ \\
\hline
\end{tabular}

ضريب كايا و دقت كلى به دسـت آمـده بـراى ايسن

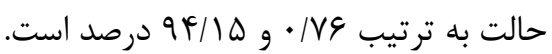

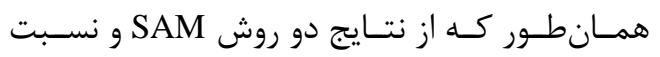

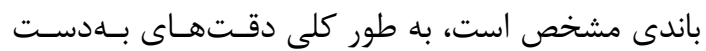

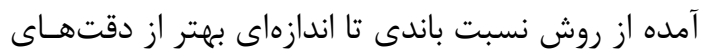

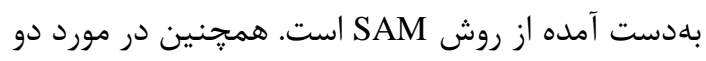

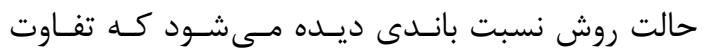
جندانى بين دقتهاى بهدسـت آمـده وجـود نـدارد. در نهايت، از بين ه حالت تست شده در اين تحقيق حالـ

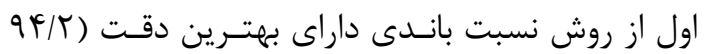

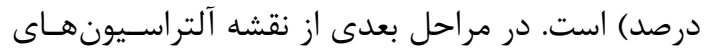

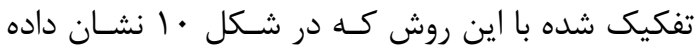
شده، به عنوان لايهاى بهمنظور تلفيق با ديخر لايهها بــه 


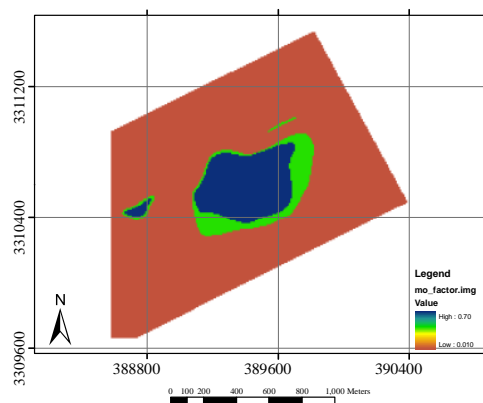

شكل سا. لايه هاله مركب موليبدن

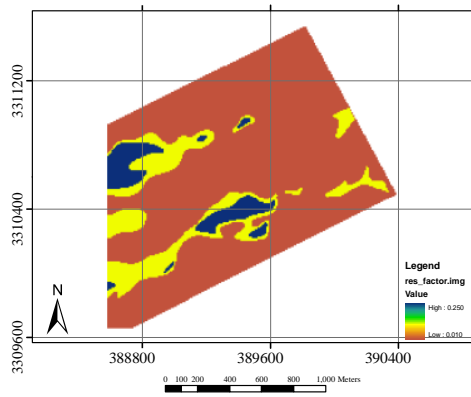

شكل 19. لايه مقاومت ظاهرى

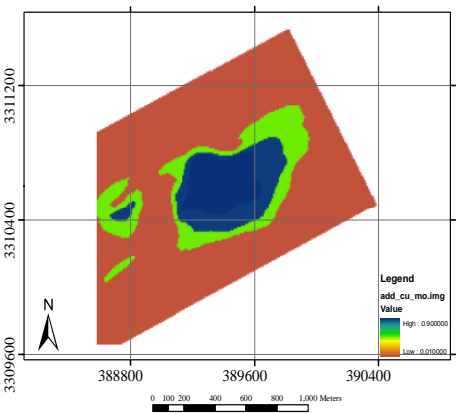

شكل rا. لايه انديسهاى اديتيو

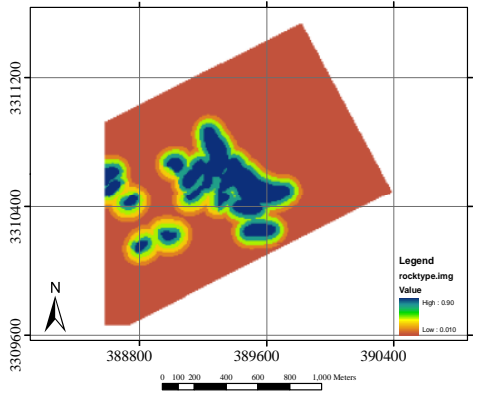

شكل ها. لايه نوع سنَ

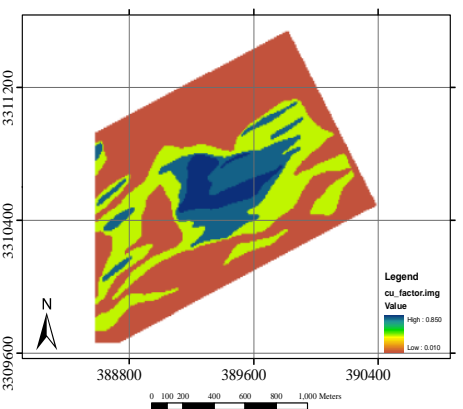

شكل Iا. لايه هاله مركب مس

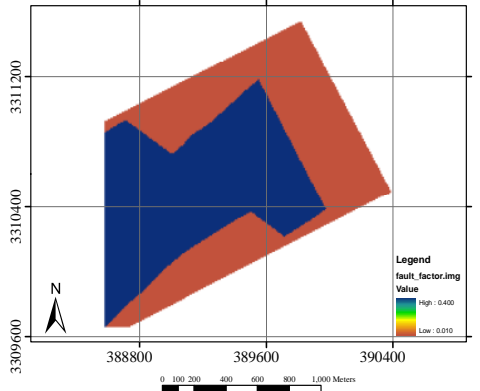

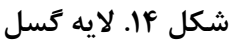

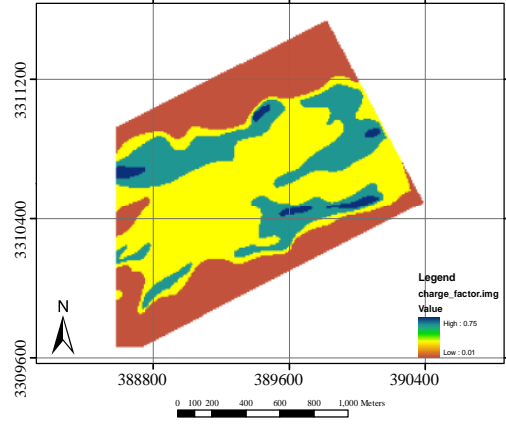

شكل 11. لايه شارزابيليته

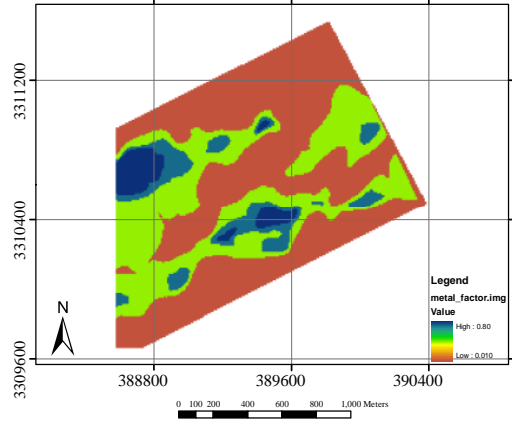

شكل VI ا. لايه فاكتور فلزى

ه-Y-Y-Y آمادهسازى دادههاى آموزشى هدف دادههاى آموزشى هدف در شبكه عصبى همان اطلاعات كمانه در محسـدوده مشـترك لايـهـهـاى اطلاعـاتى قـرار داشتند و كليه اطلاعات اين كمانهها اعم از عمـق، عيـار عنصر مس نسـبت بـه عمـق و مختصـات مكـان مرجــع كمانهها موجود است. براى اسـتخراج بـردار هـدف، بـهـ معيارى نياز است كه بهوسيله آن بتوان ميزان مطلوبيت

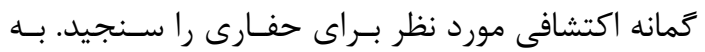

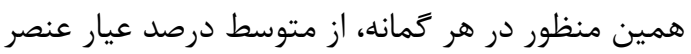


ه-ه - مدل سازى داده هاى منطقه بهوسيله شبكه عصبى و تهيه نقشه مناطق بهينه حفارى

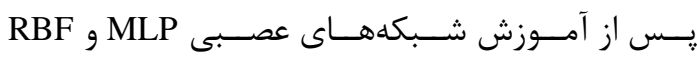
بهمنظور تعيين نقاط بهينه حفارى، لايههـاى اطلاعـاتى كل منطقه به حالت ASCII تبديل شدند. خروجى ايسن

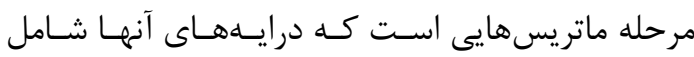

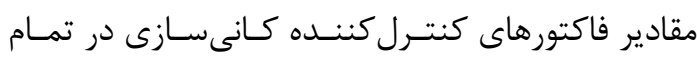

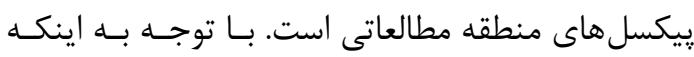

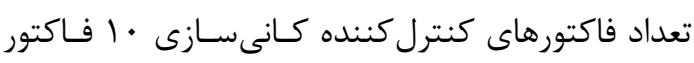

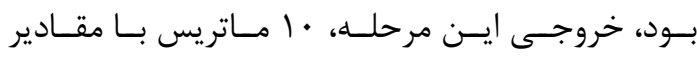

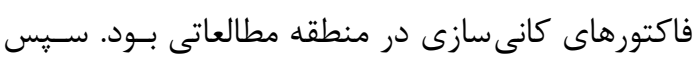

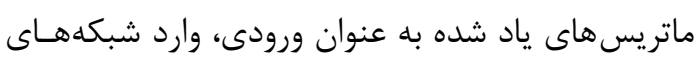

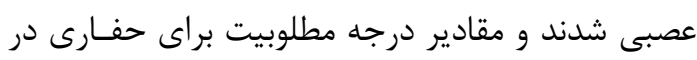

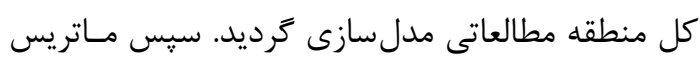

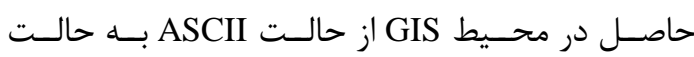

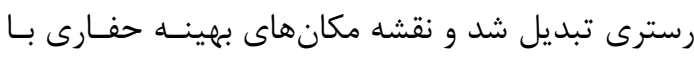

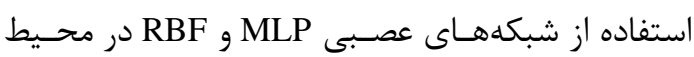

$$
\text { GIS }
$$

اين نقشهها كه در شكلهـاى 19 و و • ب نشـان داده

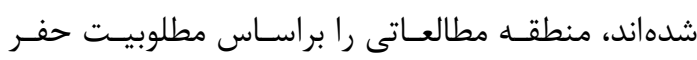

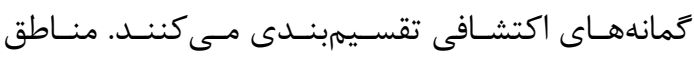

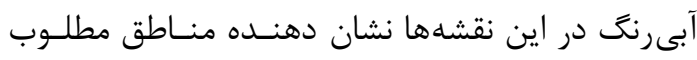

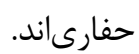

ه-9- ارزيابى نقشههاى تهيه شده

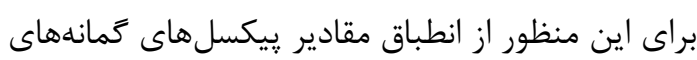

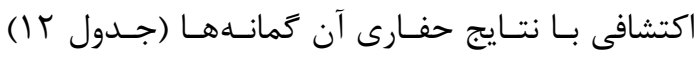

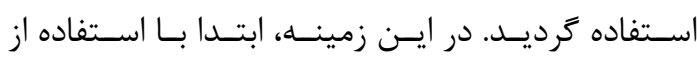

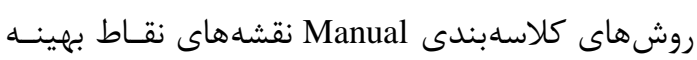
حفارى تهيه شده به صورت ســ كلاسـهـ تفكيـك شـــ

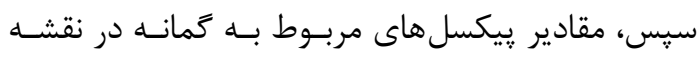

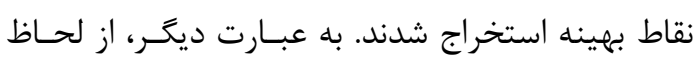

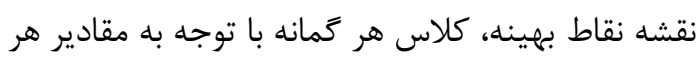

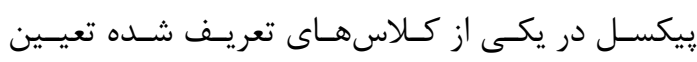
كرديد. ه-r - استخراج بردارهاى آموزشى شبكه عصبى

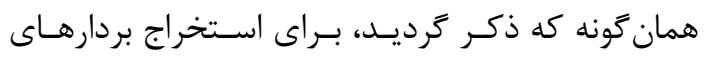
آموزشى هدف شبكه، از ميزان متوسط عيار مس نسبت

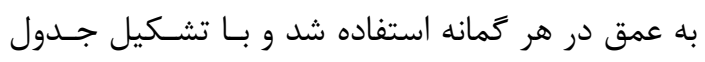

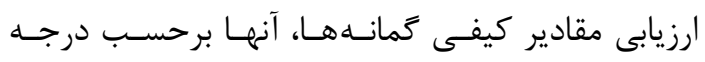

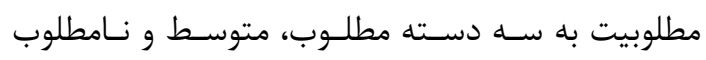

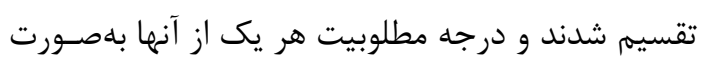
عددى تعيين گرديد.

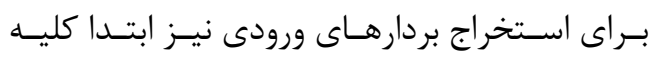

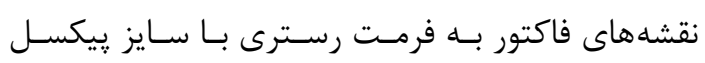
يكسان تبديل شدند و سيس به ازاى هر درايـه از بـردار

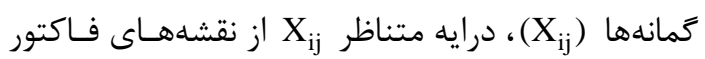
استخراج شد. بردار حاصل يك بردار شامل · ل درايسه از

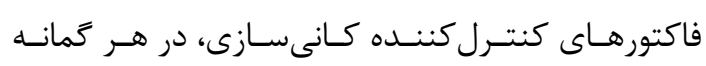

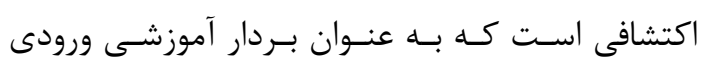
متناظر با درجه مطلوبيت هر زمانه در فراينـد آمـوزش است

$$
\text { مورد استفاده قرار مى گيرد. }
$$

ه-F- ورود داده ها به شـبـكه عصــبى و آمــوزش شبكه عصبى

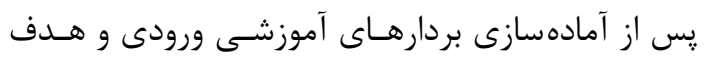
شبكه عصبى، شبكه هاى عصبى MLP و RBF بلهوسـيله

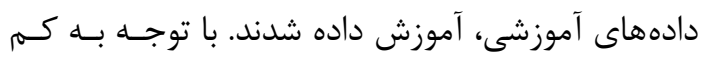

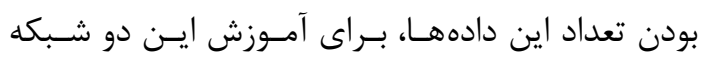

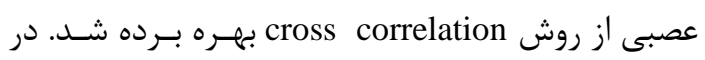

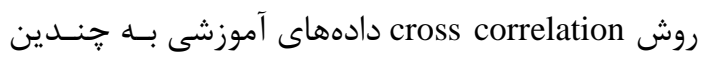

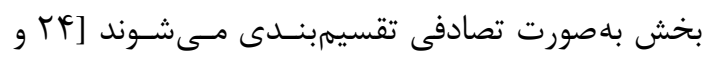

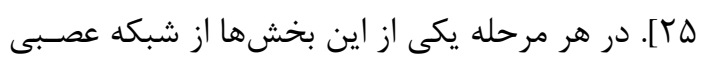

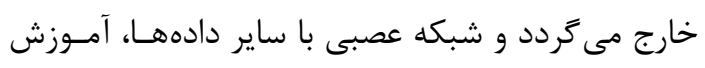

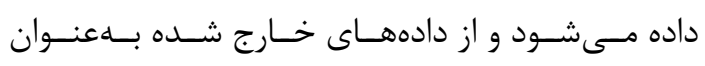
دادههايى براى آزمــون كـارايى شـبكه عصـبى اسـتفاده

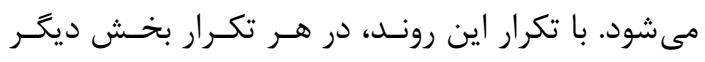

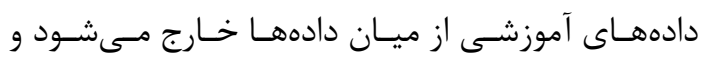

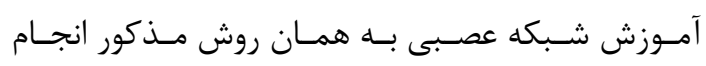

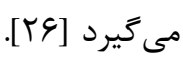




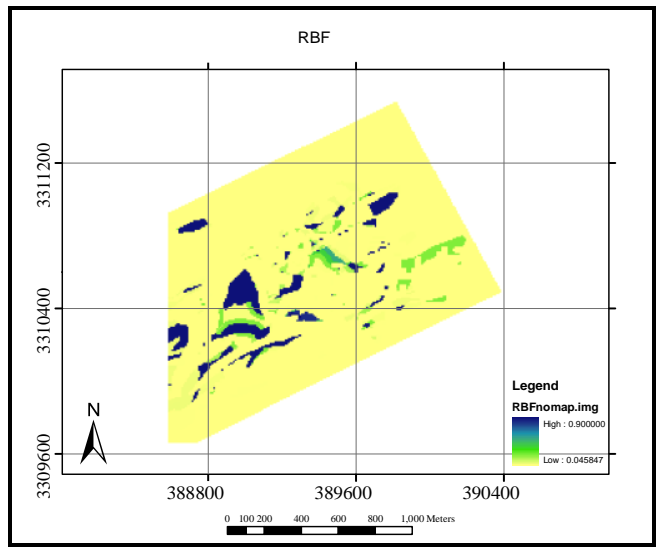

شكل ·r. نقشه مناطق بهينه حفارى، شبكه عصبى RBF

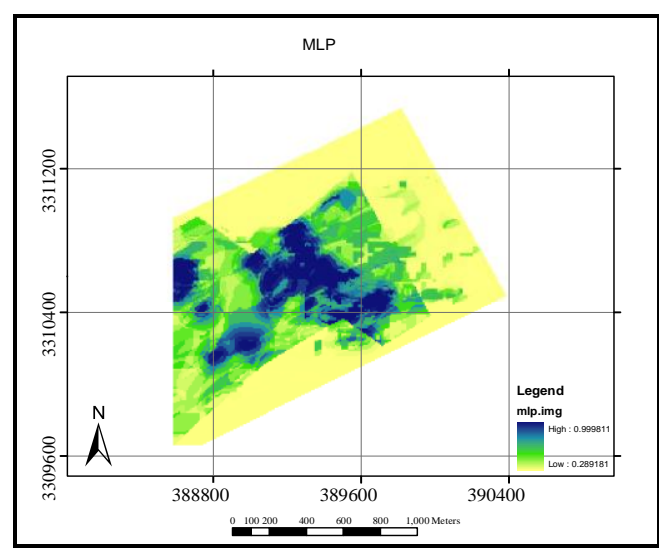

شكل19. نقشه مناطق بهينه حفارى، شبكه عصبى MLP

جدول rا. ارزيابى نهايى نقشه هاى مناطق بهينه حفارى نوجون

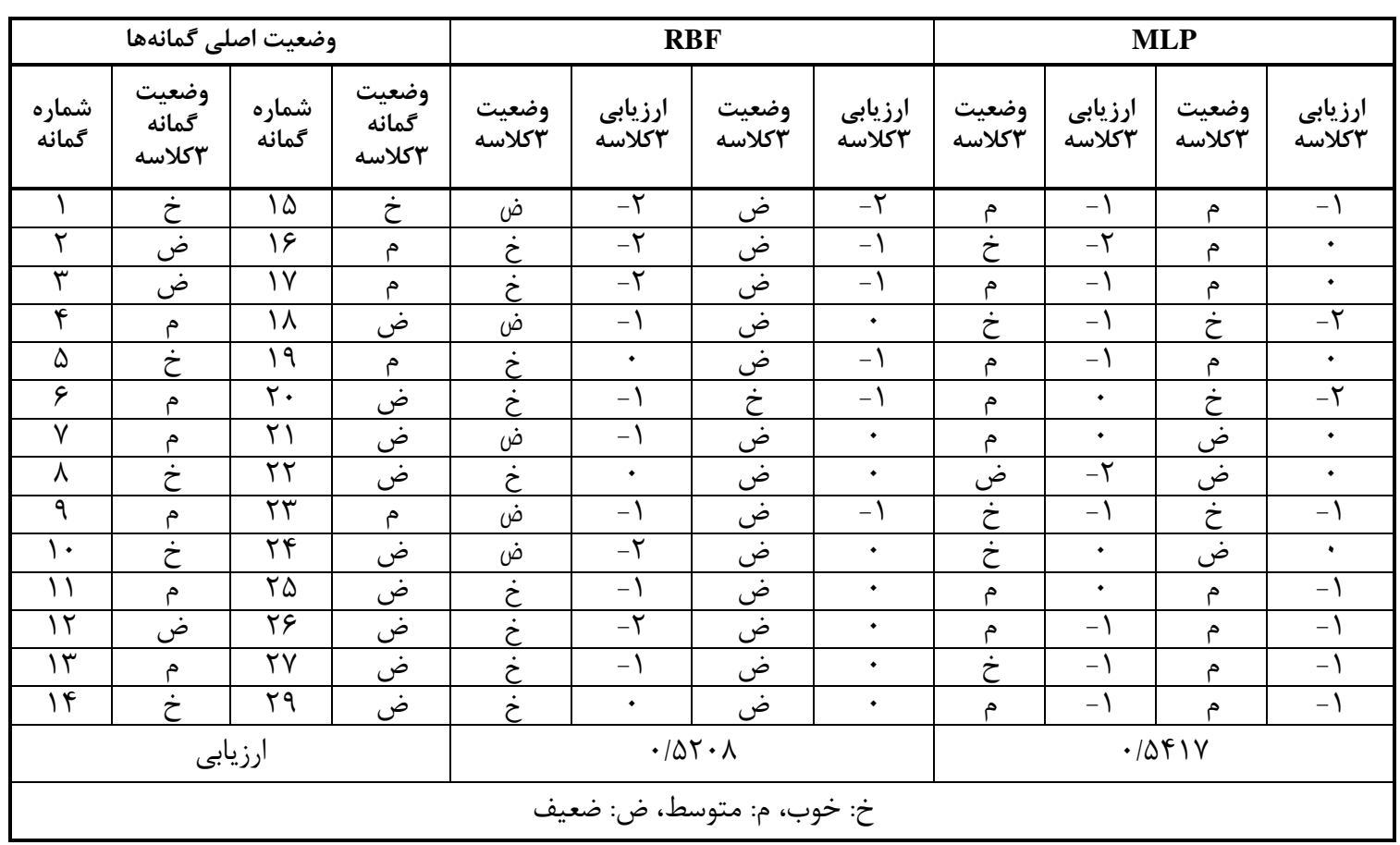

امتياز (r-) داده مىشود. امتياز ( (-) به معنى اخـتلاف

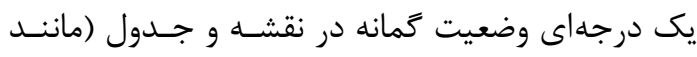
اختلاف وضعيت متوسط و وضعيت نامطلوب)، و امتيـاز (Y-) به معنى اختلاف دو درجـهاى وضـعيت گمانـه در

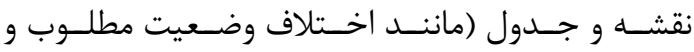
نامطلوب) بوده است. ميزان انطباق هر يك از نقشههاى تهيه شده با كمانههاى اكتشافى با استفاده از رابطه (؟)،
سيس كلاس تعيين شده براى هر گمانه با وضـعيت

آن گمانه براساس جدول كا مقايسه شد. در صورتى كه كلاس گمانه با وضعيت موجود گمانه همخــوانى داشـته

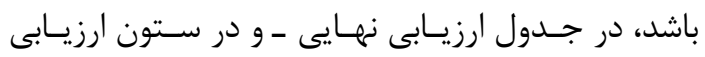

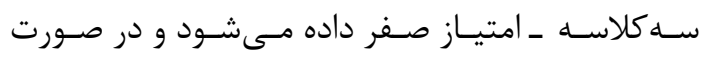
اختلاف وضعيت كلاس واقعى گمانه بـا وضـعيت كمانـهـ در نقشه، در جـدول ارزيـابى نهـايى، امتيـاز ( (-) و يـاــا 
باندى به جاى استفاده از كل منحنى طيفى از تعـدادى

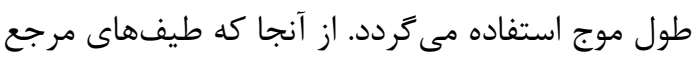

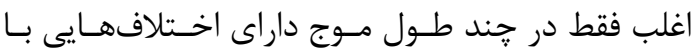
يكديخرند و در ديكر طول موجها طيـفهـا بـا يكـديكر شباهت زياد دارند، بنابراين وجود اين شباهت هائها، تمـايز طيفهاى مختلف را از يكديكر دجار مشـكل مسىسـازد

كاستى ديخر تكنيك SAM اين است كـه بـه علـت انجام محاسبات در محدودهاى از طول موجها و محاسبه

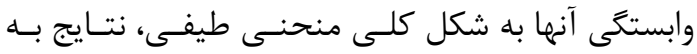

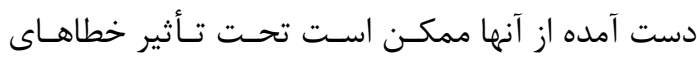

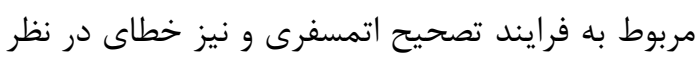
نكرفتن اختلاط غيرخطى طيفها در تكنيك جداسازى

$$
\text { طيفى خطى باشند. }
$$

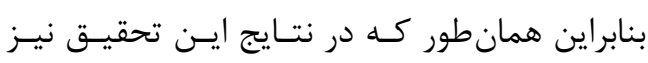

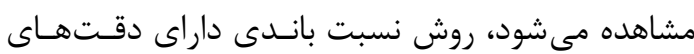

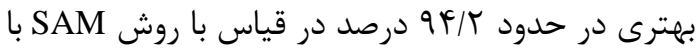
دقتى در حدود 11 درصد بوده است.

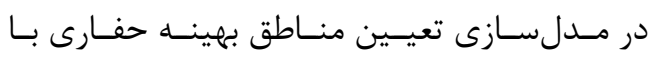

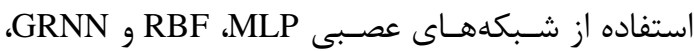
يس از انطباق لايه كَمانههـاى اكتشـافى بـا نقشـهـهـاى تهيه شده در اين تحقيق، كمترين ميزان انطباق مربوط الناه

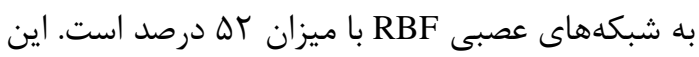

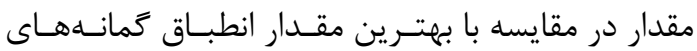
اكتشافى نقشه تهيه شده با شبكه عصـبى RBF كـه در

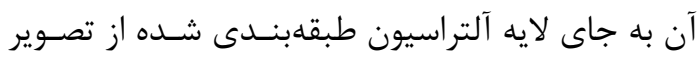
Hyperion

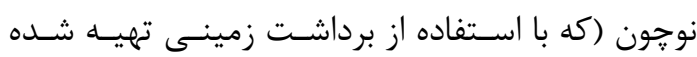

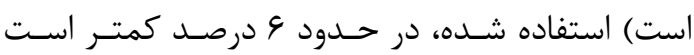

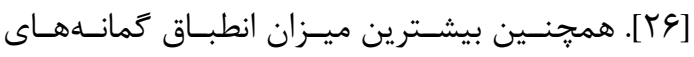
مربوط به شبكههاى عصبى MLP با ميزان انطبـاقى در حدود DF مر درصد است. اين مقدار در مقايسه با بهتـرين

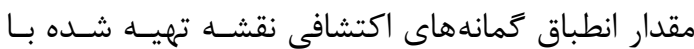
شبكه عصبى MLP كه در آن به جاى لايسه آلتراسـيون

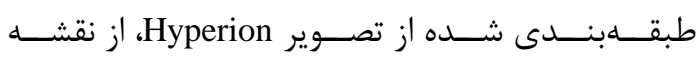

محاسبه گرديد.

$a=1-\frac{e}{E}$

رابطه (r)

در رابطه (؟)، a ميزان انطبـاق كمانـهـهـا بـا نقشـهـ

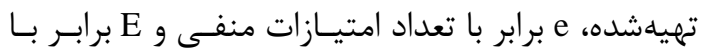
تعداد كل حالات عدم انطباق است. بــمنظــور محاســبه

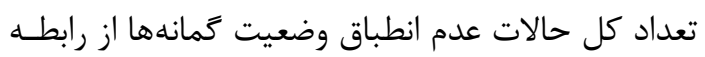

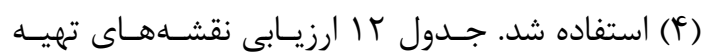
شده در انديس نوجون را نمايش مى دهد.

$$
\text { (ابطه (f) }
$$

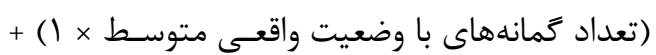

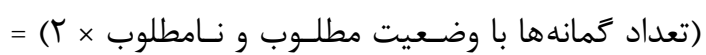
تعداد كل حالات

\section{9- ونتايج و ييشنهادها}

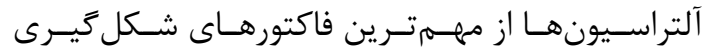

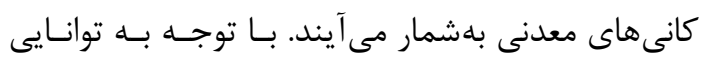

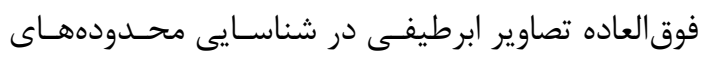

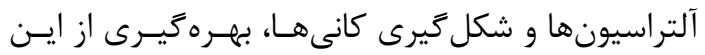

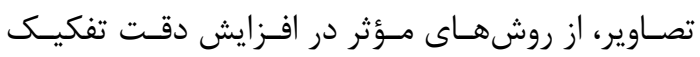

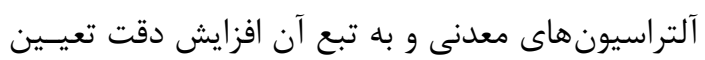
مناطق بهينه حفارى است. در اين مقاله به بررسى تفكيك آلتراسيونهاى ماسى مس إس

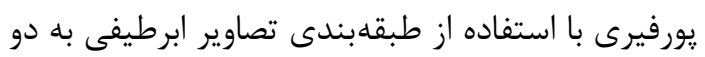

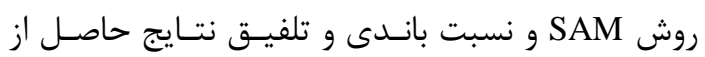

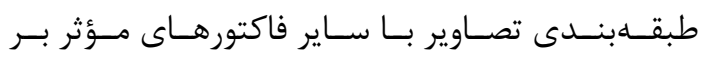

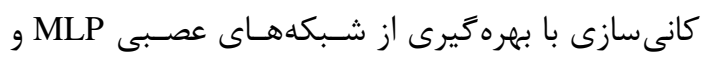

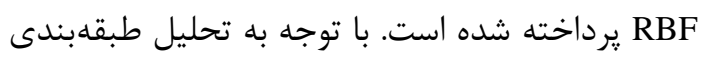
تصوير Hyperion و آناليز مدل سازى نقاط بهينه حفارى بهاري

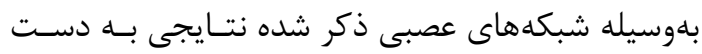
آمد كه در ادامه به آنها اشاره مي شعودي

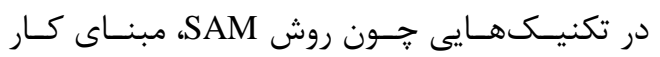
درواقع مقايسه طيف تصوير با طيف مرجع است. تعيين اين كه طيف تصوير، در جه طول موجى مولى بهترين انطباق

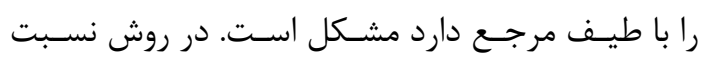


بتوانند با سرعت بيشترى بهترين باندها يا ويزگكىهـاى طيفى را براى تمايز كلاسهاى مختلف تشخيص دهند.

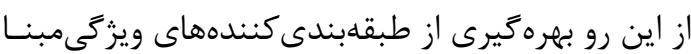
در تحقيقات آتى بيشنهاد مى رَّردد.

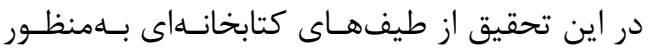

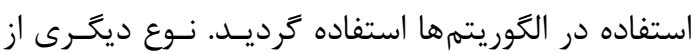
طيفها، طيفهاى خالصىى هسـتند كـهـ بـا اسـتفاده از روشهاى تعيين اعضاى خالص تصوير به دست مى آيند. קنانجه اين روشها كارآمـدى مطلـوبى داشــه باشـند، مى توان از اين منحنىهاى خالص نيز مىتـوان اسـتفاده

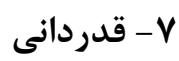

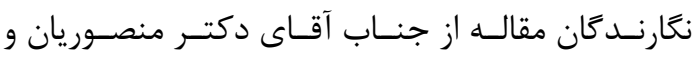

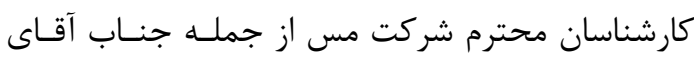
مهيندس نادر صاحبزمانى، جناب آقـاى مهنــدس اميـر

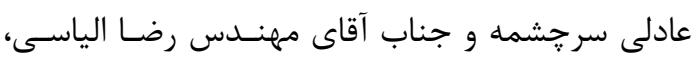
بابت همكارى صميمانهشان كمال قدردانى را دارند.

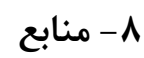

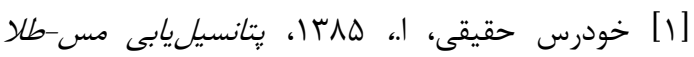

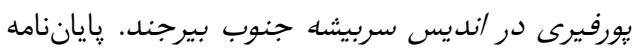

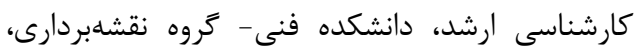

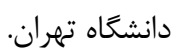

[2] Ranjbar, H., Shahriari, H. \& Honarmand, M., 2004. Integration of ASTER and Airborne Geophysical Data for Exploration of Copper Mineralization: A Case Study of Sar Cheshmeh Area. XXth International Society for Photogrammetry and Remote Sensing Congress, 4, 701-706.

[3] Frank, J.A. \& Ruitenbeek, V., 2006. Mapping White Mica and Their Absorption Wavelengths Using Hyperspectral Band Ratios. Remote Sensing of Environment, 102, 211-222.

[4] Kruse, F. A., 1988. Use of Airborne Imaging
آلتراسيونهاى معدنى منطقه نوجون استفاده شـده، تـا

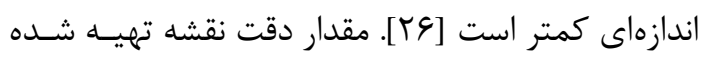
با اسـتفاده از شـبكه عصـبى RBF در ايـن تحقيـق در

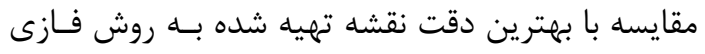

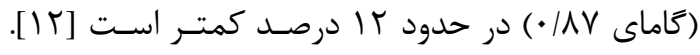

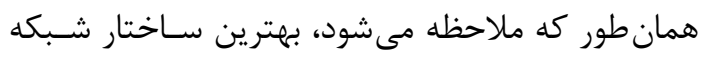

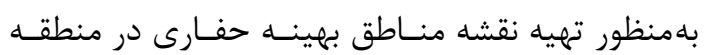
نوجون متعلق بـه شـبكههـاى عصـبى MLP بـا ميـزان انطباقى در اين تحقيق حدود ه ه درصد است. بنـابراين

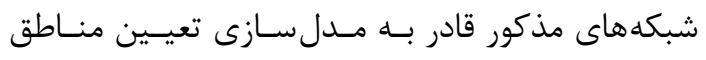
بهينه حفارى با دقتى در اين حدود هستند.

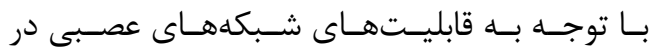

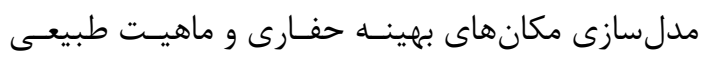

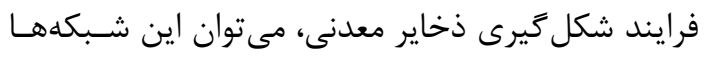

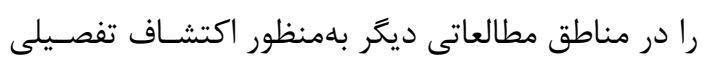

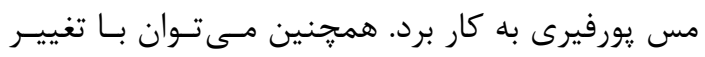

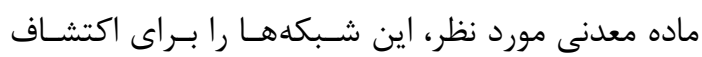

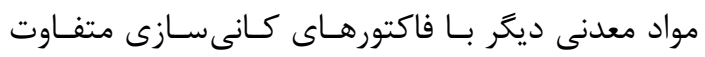

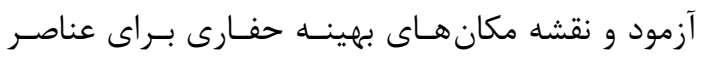

$$
\text { مختلف را ترسيم كرد. }
$$

به دليل بزرگ بودن اندازه يِيكسل ها در تصوير مورد

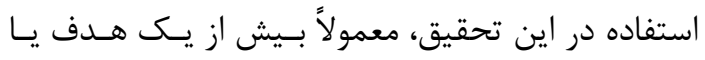

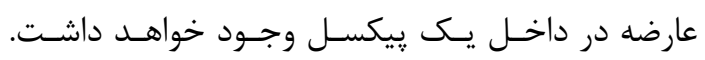

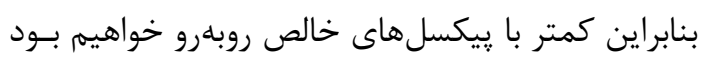

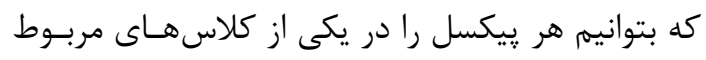

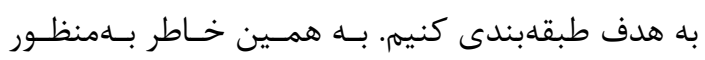

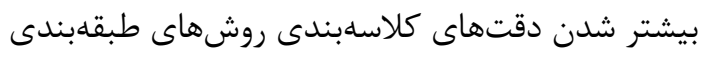

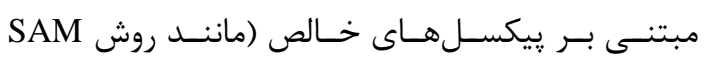

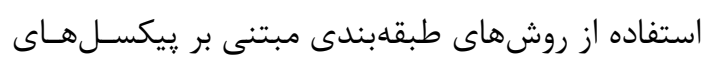

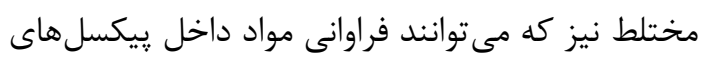
مختلط را تخمين بزنند يُ ييشنهاد مى مَردد.

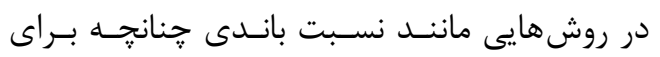

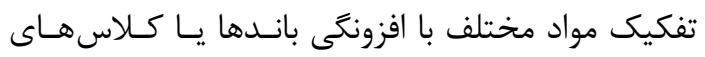

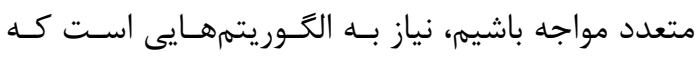
Spectrometer Data to Map Minerals 
مدلسازى تعيين نقاط بهينه حفارى با ...

امين مهرمنش و همكار ان

Associated with Hydrothermally Altered Rocks in the Northern Grapevine. Mountains, Nevada, and California. Remote Sensing of Environment, 24(1), 31-51.

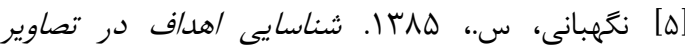

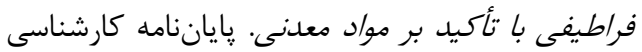

$$
\begin{aligned}
& \text { ارشد، دانشكده نقشهبردارى، دانشگاه صنعتى خواجه برانه } \\
& \text { نصير الدين طوسى. }
\end{aligned}
$$

[6] Carranza, J., 2002. GeographicallyConstrained Mineral Potential Mapping. Ph.D. Thesis, Delft University of Technology, The Netherlands, 480 pp.

[7] Sahoo, N.R., Jotimani, P. and Tripathy, G.K., 1995. Multi-Criteria Analysis in GIS Environment for Natural Resource Development: A Case Study on Gold Exploration. Tata Infotech ltd.

[8] Singer, D.A. and Kouda, R., 1997. Classification of Mineral Deposits into Types Using Mineralogy with a Probabilistic Neural Network. Nonrenewable Resources, 6, 27-32.

[9] Singer, D.A. and Kouda, R.A., 1999. Comparision of the Weights-of-evidence Method and Probabilistic Neural Networks. Natural Resources Research, 8(4), 287-298.

[10] Hosseinali, F. and Alesheikh, A.A., 2008. Weighting Spatial Information in GIS for Copper Mining Exploration. journal of Applied Science, 5(9), 1187-1198.

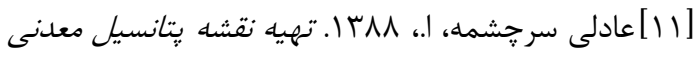

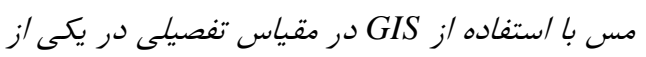

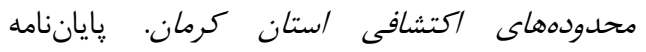

$$
\begin{aligned}
& \text { كارشناسى ارشد، دانشكده فنى - عروه نقشهبردارى، } \\
& \text { دانشعاه تهران. }
\end{aligned}
$$

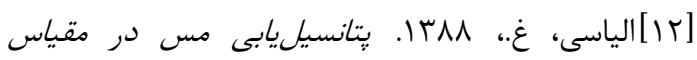

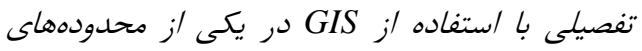

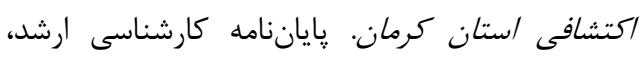

$$
\begin{aligned}
& \text { دانشكده فنى - ₹روه نقشه بردارى، دانشعاه تهران. }
\end{aligned}
$$

[13] Sanchez, J.P. et al., 2003. Artificial Neural
Network as a Tool for Mineral Potential Mapping with GIS. Journal of Remote Sensing, 24 (5), 1151-1156.

[14] Porwal, A. et al., 2004. A Hybrid Neuro Fuzzy Model for Mineral Potential Mapping. journal of Mathematical Geology, 36(7), 803-826.

[15] Girouard, G., 2004. Validated Spectral Angle Mapper Algorithm for Geological Mapping Comparative Study between Quickbird and Landsat-TM. ISPRS conferences.

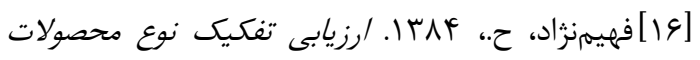

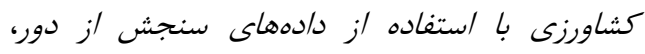

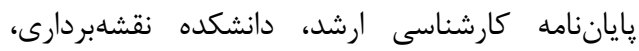

$$
\begin{aligned}
& \text { دانشخاه صنعتى خواجه نصيرالدين طوسى. }
\end{aligned}
$$

[17]Jacob, T., 2007. Partial Unmixing of Hyperspectral Imagery: Theory and Methods. ASPRS Annual conference.

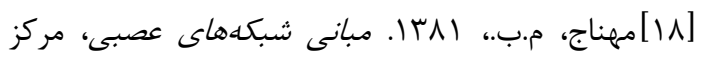

$$
\begin{aligned}
& \text { نشر دانشگاه صنعتى اميركبير. }
\end{aligned}
$$

[19] Hagan, M.T., Demuth, H.B. \& Beale, M.H., 1996. Neural Networks Design. PWS Publishing Company, Boston.

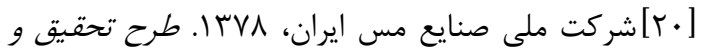

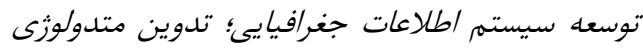

$$
\begin{aligned}
& \text { تعيين نقاط حفارى با /ستفاده /ز GIS. }
\end{aligned}
$$

[21]Beck, R., 2003. EO-1 User Guide v. 2.3. Department of Geography University of Cincinnati.

[22] http: Ileo-1.gsfc.nasa.gov, 2001. EO-1 Technology Validation Extended Mission Questionnaire Background Data and Operation Assumptions.

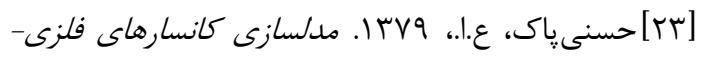

$$
\begin{aligned}
& \text { غيرفلزى و كاربرد اكتشافى آنها. انتشارات دانشعاه }
\end{aligned}
$$

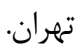

[24]Bishop, C.M., 1995. Neural Networks for Pattern Recognition. 1st edition. Oxford Clarendon. 
[25] Yugoslavia report, 1972. Report on Explorations for Copper in Now Chun Area. Institute for geological and mining exploration Beograd-Yugoslavia , 1-39.

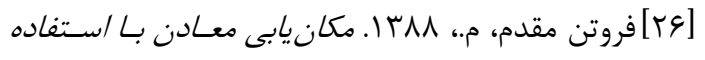

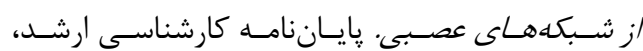

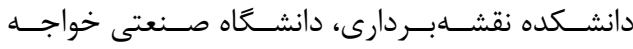

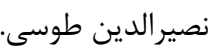




\title{
Determining the Optimum Position of Boreholes, Using Hyperion Image and Neural Networks Method
}

\author{
Mehrmanesh, A. ${ }^{1 *}$, ValadanZouj M.J. ${ }^{2}$, Sahebi M.R. ${ }^{3}$, Forutan M. ${ }^{4}$, Soltani M. ${ }^{5}$ \\ 1- M.Sc. in GIS, K.N. Toosi University of Technology \\ 2- Associate Prof., K.N. Toosi University of Technology \\ 3- Assistant Prof., K.N. Toosi University of Technology \\ 4- M.Sc. in GIS, K.N. Toosi University of Technology \\ 5- Refearche in Advanced Information \& Communication Technology Center, Sharif University of Technology
}

\begin{abstract}
Among detailed mineral exploration studies, the alteration mapping has been proved to be the fundamental objective for identifying the deposits formation. This paper aims determining alteration zones in Hyperspectral images with the assist of SAM \& Band Ratio methods at first. The second interest is integrating the output of determined alteration zones by other mineralization factors using different Neural Networks namely Multilayer pecreptrons, Radial Basis Function \& Generalized Neural Network and using cross correlation method. This integration is performed for determining the position of boreholes of porphyry copper exploration in Nowchoun region. In the case of Hyperspectral classification, the best result have been achieved by the band ratio method, i.e. about 94.2 percent. Eventually, the degree of correlation between maps that produced by neural networks and operated exploration boreholes have been estimated. Comparison between the high potential points indicated by our maps with those previous drilled boreholes reveals that MLP network has the highest correlation. This correlation is about $54 \%$ in Nowchoun region.
\end{abstract}

Keywords: Hyperspectral image, Alteration, Porphyry copper, Neural Networks, Hyperion.

Correspondence Address: Faculty of Geodesy \& Geomatics Engineering, K.N. Toosi University of Techenology, No. 1346, Vali-asr Ave., Mirdamad Cross, Tehran, Iran. Tel: +98 2188786212

Email: amin1174@gmail.com 